\title{
Epstein-Barr Virus-Associated Malignancies and Immune Escape: The Role of the Tumor Microenvironment and Tumor Cell Evasion Strategies
}

\author{
Marcus Bauer ${ }^{1}\left(\mathbb{D}\right.$, Simon Jasinski-Bergner ${ }^{2}$, Ofer Mandelboim ${ }^{3}$, Claudia Wickenhauser ${ }^{1,+}$ \\ and Barbara Seliger $2,4, *,+(\mathbb{D}$
}

1 Department of Pathology, Martin Luther University Halle-Wittenberg, Magdeburger Str. 14, 06112 Halle (Saale), Germany; marcus.bauer@uk-halle.de (M.B.); claudia.wickenhauser@uk-halle.de (C.W.)

2 Department of Medical Immunology, Martin Luther University Halle-Wittenberg, Magdeburger Str. 2, 06112 Halle (Saale), Germany; simon.jasinski@uk-halle.de

3 Department of Immunology, Faculty of Medicine, The Hebrew University of Jerusalem, En Kerem, P.O. Box 12271, Jerusalem 91120, Israel; oferm@ekmd.huji.ac.il

4 Fraunhofer Institute for Cell Therapy and Immunology, Perlickstr. 1, 04103 Leipzig, Germany

* Correspondence: Barbara.seliger@uk-halle.de; Tel.: +49-(345)-557-1357

+ Shared senior authorship.

\section{check for} updates

Citation: Bauer, M.; Jasinski-Bergner, S.; Mandelboim, O.; Wickenhauser, C.; Seliger, B. Epstein-Barr

Virus-Associated Malignancies and Immune Escape: The Role of the Tumor Microenvironment and Tumor Cell Evasion Strategies. Cancers 2021, 13, 5189. https://doi.org/10.3390/ cancers13205189

Academic Editors: Lorenzo Leoncini and Lucia Mundo

Received: 20 September 2021

Accepted: 11 October 2021

Published: 16 October 2021

Publisher's Note: MDPI stays neutral with regard to jurisdictional claims in published maps and institutional affiliations.

Copyright: (C) 2021 by the authors Licensee MDPI, Basel, Switzerland. This article is an open access article distributed under the terms and conditions of the Creative Commons Attribution (CC BY) license (https:/ / creativecommons.org/licenses/by/ $4.0 /)$.
Simple Summary: The Epstein-Barr virus, also termed human herpes virus 4, is a human pathogenic double-stranded DNA virus. It is highly prevalent and has been linked to the development of 1-2\% of cancers worldwide. EBV-associated malignancies encompass various structural and epigenetic alterations. In addition, EBV-encoded gene products and microRNAs interfere with innate and adaptive immunity and modulate the tumor microenvironment. This review provides an overview of the characteristic features of EBV with a focus on the intrinsic and extrinsic immune evasion strategies, which contribute to EBV-associated malignancies.

Abstract: The detailed mechanisms of Epstein-Barr virus (EBV) infection in the initiation and progression of EBV-associated malignancies are not yet completely understood. During the last years, new insights into the mechanisms of malignant transformation of EBV-infected cells including somatic mutations and epigenetic modifications, their impact on the microenvironment and resulting unique immune signatures related to immune system functional status and immune escape strategies have been reported. In this context, there exists increasing evidence that EBV-infected tumor cells can influence the tumor microenvironment to their own benefit by establishing an immune-suppressive surrounding. The identified mechanisms include EBV gene integration and latent expression of EBV-infection-triggered cytokines by tumor and/or bystander cells, e.g., cancer-associated fibroblasts with effects on the composition and spatial distribution of the immune cell subpopulations next to the infected cells, stroma constituents and extracellular vesicles. This review summarizes (i) the typical stages of the viral life cycle and EBV-associated transformation, (ii) strategies to detect EBV genome and activity and to differentiate various latency types, (iii) the role of the tumor microenvironment in EBV-associated malignancies, (iv) the different immune escape mechanisms and (v) their clinical relevance. This gained information will enhance the development of therapies against EBV-mediated diseases to improve patient outcome.

Keywords: EBV; EBV-associated malignancies; malignant transformation; tumor microenvironment; immune escape

\section{Introduction}

The Epstein-Barr virus (EBV), described in 1964 by Michael Anthony Epstein and Yvonne Barr in African endemic Burkitt lymphoma (BL) samples, was the first discovered human-tumor-associated virus [1,2]. This knowledge provided important insights into the 
involvement of viruses in the pathogenesis of human malignancies and the natural history of human herpes viruses (HHVs). EBV, also known as human herpes virus 4 (HHV4), a family member of the gamma herpesviridae, is characterized by a high transmission rate and a spread of infection in more than $90 \%$ of the world population [3]. The virus consists of a 170-180 kb linear double-stranded (ds) enveloped DNA with a toroid-shaped protein core, a nucleocapsid with 162 capsomers and external virus-encoded glycoprotein spikes on the surface of the viral tegument [4-6]. The viral genome encodes more than 85 genes, which, to a distinct extent, contribute to the mechanisms of EBV infection and to the initiation and clinical manifestation of EBV-associated human diseases. For 30 to $40 \%$ of EBV genes, very little is known concerning their specific function [7]. So far, two major EBV types, named type 1 and type $2 \mathrm{EBV}$, with nearly identical genomes except for the genes encoding some of the nuclear proteins, the EBV nuclear antigen (EBNA)-2 and EBNA-3A, $-3 \mathrm{~B}$ and $-3 \mathrm{C}$, have been identified $[8,9]$. Type $1 \mathrm{EBV}$ is found ubiquitously worldwide and has a higher transformation efficiency of B cells, while type $2 \mathrm{EBV}$ is mainly detected in Africa $[10,11]$. Primary infection mostly involves asymptomatic children prior to the age of 5 years and is rather rare in adults who more frequently acquire severe symptoms called infectious mononucleosis [12]. After the primary infection, the virus shows a life-long persistence in memory B cells [13]. In general, EBV establishes different life-cycle programs consisting of the primary infection, the latency and the lytic program [2]. Within the lytic program of infection, new infectious virions are produced, while the latent form of infection allows the virus to persist in host cells [14]. The majority of EBV-infected individuals control the infection by cytotoxic immune cell responses via natural killer (NK) cells and CD8 ${ }^{+} \mathrm{T}$ lymphocytes $[3,15]$. Only a small number of infected individuals develop chronic EBV-associated pathologies, which are often related to immune deficiencies, genetic pre-disposition and environmental factors [16]. Chronic EBV infection of different tissues of mainly epithelial and lymphocytic origin has been associated with malignant diseases such as carcinomas, lymphomas/lymphoproliferative disorders and soft-tissue tumors [17-21]. Geographically, EBV-associated neoplasia is present worldwide but is more frequent in Asia and Africa compared to the Western world [17,22-25] with a higher incidence in males than in females $[2,26]$. Furthermore, different EBV-associated tumor entities present distinct peaks in the disease onset. In detail, endemic BL is primarily a disease of young children between 2 and 20 years of age. In contrast, EBV-positive nasopharyngeal carcinoma (NPC) and gastric carcinoma (GC) occur in adults between 18 and 80 years with EBV-positive GC patients frequently younger than 60 years $[17,18,20,26-28]$. A comprehensive summary concerning the geographic and epidemiologic peculiarities of EBV-associated malignancies is shown in Table 1.

Table 1. Epidemiological features of EBV-associated neoplasia.

\begin{tabular}{|c|c|c|c|c|c|}
\hline Disease & $\begin{array}{c}\text { Prevalence of } \mathrm{EBV}^{+} \\
\text {Diseases }\end{array}$ & $\begin{array}{l}\text { Frequency of EBV } \\
\text { Infection within the } \\
\text { Tumor Entity }\end{array}$ & $\begin{array}{c}\text { Age at Disease } \\
\text { Onset }\end{array}$ & $\begin{array}{l}\text { Geographic } \\
\text { Distribution }\end{array}$ & References \\
\hline \multicolumn{6}{|c|}{ Carcinomas } \\
\hline $\begin{array}{l}\text { nasopharyngeal } \\
\text { carcinoma (NPC) }\end{array}$ & $\begin{array}{l}\text { 1:100,000 in Europe } \\
25: 100,000 \text { in Asia }\end{array}$ & $\sim 90 \%$ & $18-80$ years & $\begin{array}{c}\text { South East Asia, } \\
\text { North and East } \\
\text { Africa }\end{array}$ & {$[17,22]$} \\
\hline $\begin{array}{c}\text { gastric } \\
\text { adenocarcinoma } \\
\text { (GC) }\end{array}$ & 1:100,000 & $\sim 9 \%$ & frequently $<60$ years & worldwide & {$[18,27,28]$} \\
\hline $\begin{array}{c}\text { intrahepatic } \\
\text { cholangiocarcinoma } \\
\text { (ICC) }\end{array}$ & $<0.01: 100,000$ & $6.6 \%$ & $24-68$ years & South East Asia & {$[23,29,30]$} \\
\hline \multicolumn{6}{|c|}{ Lymphomas and lymphoproliferative disorders } \\
\hline $\begin{array}{l}\text { chronic active EBV } \\
\text { infection (CAEBV) }\end{array}$ & rare & $100 \%$ & $5-31$ & Asia & {$[31,32]$} \\
\hline mucocutaneous ulcer & unknown & $100 \%$ & $>60$ years & worldwide & {$[25,33]$} \\
\hline
\end{tabular}


Table 1. Cont.

\begin{tabular}{|c|c|c|c|c|c|}
\hline Disease & $\begin{array}{c}\text { Prevalence of } \mathrm{EBV}^{+} \\
\text {Diseases }\end{array}$ & $\begin{array}{l}\text { Frequency of EBV } \\
\text { Infection within the } \\
\text { Tumor Entity }\end{array}$ & $\begin{array}{c}\text { Age at Disease } \\
\text { Onset }\end{array}$ & $\begin{array}{l}\text { Geographic } \\
\text { Distribution }\end{array}$ & References \\
\hline $\begin{array}{l}\text { lymphomatoid } \\
\text { granulomatosis }\end{array}$ & rare & $\sim 100 \%$ & $\begin{array}{l}\text { typically adults, rare } \\
\text { in childhood }\end{array}$ & $\begin{array}{c}\text { Europe and North } \\
\text { America }\end{array}$ & {$[34,35]$} \\
\hline $\begin{array}{l}\text { extranodal NK/T cell } \\
\text { lymphoma (ENKTL) }\end{array}$ & rare & $100 \%$ & 17-89 years & Asia & {$[36,37]$} \\
\hline $\begin{array}{l}\text { classical Hodgkin } \\
\text { lymphoma (cHL) }\end{array}$ & $\begin{array}{c}\text { 0.5:100,000 in Asia } \\
2.3: 100,000 \text { in Europe }\end{array}$ & $\begin{array}{l}50-90 \% \text { depending } \\
\text { on the subtype }\end{array}$ & $20-65$ & worldwide & [19] \\
\hline $\begin{array}{l}\text { plasmablastic } \\
\text { lymphoma }\end{array}$ & $0.1: 100,000$ & $80 \%$ & $7-65$ years & worldwide & {$[25,38]$} \\
\hline $\begin{array}{l}\text { post-transplant } \\
\text { lymphoproliferative } \\
\text { disease (PTLD) }\end{array}$ & $\begin{array}{c}<1 \% \text { in bone marrow } \\
\text { transplanted } \\
\text { up to } 30 \% \text { in small } \\
\text { bowel transplanted } \\
\text { patients }\end{array}$ & $60-80 \%$ & $\begin{array}{c}\text { children more often } \\
\text { affected }\end{array}$ & worldwide & [39] \\
\hline $\begin{array}{l}\text { angioimmunoblastic } \\
\text { T-cell lymphoma } \\
\text { (AITL) }\end{array}$ & $0.05-0.2: 100,000$ & $\sim 70 \%$ & 20-86 years & Europe & {$[40-42]$} \\
\hline $\begin{array}{c}\text { primary effusion } \\
\text { lymphoma }\end{array}$ & rare & $70 \%$ & young adults & worldwide & {$[25]$} \\
\hline $\begin{array}{l}\text { Burkitt lymphoma } \\
\text { (BL) sporadic }\end{array}$ & $0.15: 100,000$ & $<15 \%$ & $15-40$ years & worldwide & {$[43]$} \\
\hline $\begin{array}{l}\text { Burkitt lymphoma } \\
\text { (BL) endemic }\end{array}$ & $3-6: 100,000$ & $>90 \%$ & 2-20 years & $\begin{array}{l}\text { Central Africa } \\
\text { East Africa }\end{array}$ & {$[20]$} \\
\hline $\begin{array}{l}\text { diffuse large B-cell } \\
\text { lymphoma (DLBCL) }\end{array}$ & $5-7: 100,000$ & $\begin{array}{l}\text { Europe } \sim 4 \% \\
\text { Asia } \sim 15 \%\end{array}$ & 50-91 years & Asia & {$[24,25,44]$} \\
\hline \multicolumn{6}{|c|}{ Soft-tissue tumors } \\
\hline $\begin{array}{l}\text { leiomyosarcoma } \\
\text { associated with } \\
\text { immune suppression }\end{array}$ & rare & $100 \%$ & $\begin{array}{l}\text { children and } \\
\text { adolescents }\end{array}$ & worldwide & {$[45]$} \\
\hline $\begin{array}{c}\mathrm{EBV}^{+} \text {inflammatory } \\
\text { follicular dendritic } \\
\text { cell sarcoma }\end{array}$ & rare & Unknown & $8-77$ years * & worldwide & {$[21,46]$} \\
\hline
\end{tabular}

* Data from 9 cases.

\section{Viral Life Cycle and EBV-Associated Transformation}

EBV infections have a high prevalence in the world population of more than $90 \%$ and show a life-long latency in the host. The primary EBV infection occurs via orally transmitted virions infecting resting $B$ cells and the oral epithelium, although it remains largely unclear whether the B cells or the epithelial cells are infected first [2,47]. While the exact mechanism of viral entry in these epithelial host cells is under discussion, the viral entry into naïve $\mathrm{B}$ cells is initiated by attachment of the EBV glycoprotein (gp) gp350 to the CD21 surface molecule known as complement C3d receptor 2 (CR2) that is selectively expressed on lymphoid cells [48]. For persistent EBV infection, the virus has to enter the circulating memory B-cell pool as reviewed elsewhere [2,49]. Within this process, EBV shows different latency types that are characterized by a distinct expression pattern of a limited number of EBV genes. Within the circulating memory B cells, the EBV infection passes into the most restricted latency type 0 . This latency type is characterized by the sole expression of noncoding genes, including EBER transcripts, BARTs (BamHI fragment A rightward transcript) and several microRNAs (miRs) [50]. Three further latency types can be distinguished, which are characterized by the differential expression of five EBV-encoded nuclear antigens (EBNAs), two latent membrane proteins (LMPs), two EBV-encoded small RNAs (EBERs) and non-coding BART RNAs [51]. A detailed summary of the distinct gene expression profiles observed in the latency phase types 0, I, II and III of EBV infection has been recently reviewed and is provided in Table 2 [51-53]. 
Table 2. EBV-associated gene and protein expression profiles, allocated latency type and related diseases.

\begin{tabular}{|c|c|c|c|}
\hline Latency Type & $\begin{array}{c}\text { Gene Expression Profile } \\
\text { Associated with Latent EBV } \\
\text { Expression }\end{array}$ & $\begin{array}{c}\text { Diseases with Strong } \\
\text { Association to a Certain Latency } \\
\text { Type }\end{array}$ & $\begin{array}{c}\text { Diseases with Variable Latency } \\
\text { Types }\end{array}$ \\
\hline \multirow[t]{2}{*}{$0 / \mathrm{I}$} & $\begin{array}{c}\text { EBERs } \\
\text { EBNA-1, } \\
\text { BART (miRs) }\end{array}$ & $\begin{array}{c}\text { endemic or sporadic Burkitt } \\
\text { lymphoma (BL), } \\
\text { plasmablastic lymphoma, } \\
\text { primary effusion lymphoma }\end{array}$ & $\begin{array}{c}\text { nasopharyngeal carcinoma (NPC), } \\
\text { astric adenocarcinoma (GC), } \\
\text { intrahepatic cholangiocarcinoma } \\
\text { (ICC), }\end{array}$ \\
\hline & & & NK cell leukemia, \\
\hline \multirow[t]{4}{*}{ II } & $\begin{array}{c}\text { EBERs } \\
\text { EBNA-1 } \\
\text { LMP-1,-2A, -2B } \\
\text { BART (miRs) }\end{array}$ & $\begin{array}{l}\text { classical Hodgkin lymphoma, } \\
\text { EBV-positive diffuse large B-cell } \\
\text { lymphoma (DLBCL), not } \\
\text { otherwise specified (NOS) } \\
\text { extranodal NK/T cell }\end{array}$ & $\begin{array}{c}\text { angioimmunoblastic T-cell } \\
\text { lymphoma (AITL), chronic active } \\
\text { EBV infection of T- and NK-cell } \\
\text { type (CAEBV) }\end{array}$ \\
\hline & & $\begin{array}{l}\text { lymphoma, } \\
\text { leiomyosarcoma associated with }\end{array}$ & \\
\hline & & immune suppression & $\begin{array}{l}\text { DLBCL associated with chronic } \\
\text { inflammation }\end{array}$ \\
\hline & & & mucocutaneous ulcer \\
\hline III & $\begin{array}{c}\text { EBERs } \\
\text { EBNA-1, -2, 3A, -3B, -3C } \\
\text { LMP-1, -2A, -2B } \\
\text { BHRF1 } \\
\text { BART (miRs) }\end{array}$ & infectious mononucleosis & $\begin{array}{c}\text { lymphomatoid granulomatosis, } \\
\text { post-transplant } \\
\text { lymphoproliferative disorders } \\
\text { (PTLD) }\end{array}$ \\
\hline
\end{tabular}

Furthermore, a lytic EBV infection, which occurs in both immunocompetent and immuno-incompetent hosts as part of the primary infection of the oropharynx, can be distinguished from the latent infection types [54]. Three different lytic phases have been described, namely immediate early, early and late phases, which are associated with the expression of more than 80 lytic genes [50]. Within lytic infection, host cells are destroyed and new infectious virions are released. The expression of the immediate early transcription factor Zta, which is encoded in the BZLF1 gene and Rta (BRLF1 gene product), initiates this lytic phase [55-57].

Since the first discovery of EBV in African endemic BL samples in 1964, the malignant transformation capacity of EBV-infected cells has been extensively investigated. Interestingly, despite an infection rate of over $90 \%$, only $1.8 \%$ of worldwide cancer deaths can be attributed to EBV-associated malignancies [58,59]. EBV-associated malignancies express different EBV latent gene products with oncogenic potential that help to distinguish between distinct entities in the diagnostic setting [60]. The EBV gene products of BALF1 and BHRF1, which are BCL-2 homologs with anti-apoptotic functions, are both known to be involved in B-cell transformation [61,62]. Furthermore, the EBV latent gene products interfere with the innate and adaptive immunity by modulating the tumor microenvironment (TME) and thereby supporting tumor progression, which is discussed in detail in Sections 4.3 and 4.4. In addition, EBV-encoded miRs such as miR-BHRF1-1, miR-BHRF1-2 and miR-BHRF1-3 [63] are expressed during EBV latency type III infection and the lytic phase. These miRs are also known to inhibit apoptosis and enhance cell-cycle progression in the early phase of B-cell infection [62]. MiRs are small 19-24-nucleotide-long non-coding single-stranded RNAs involved in the post-transcriptional gene regulation, preferentially but not exclusively binding to the $3^{\prime}$ untranslated region (UTR) of their targets, leading to a translational inhibition and mRNA decay or mRNA storage [64-66]. MiRs are usually expressed in eukaryotes, but certain DNA viruses, including herpes viruses, can also encode for miRs, which potentiate their transforming properties and mediate immune escape mechanisms $[57,67,68]$. Recently, the role of non-coding RNAs of EBV with a focus on EBERs and miRs in EBV-mediated tumorigenesis and immune control has been extensively reviewed and is referred to for additional information [53]. Furthermore, an influence of lytic gene expression in the process of malignant transformation has been shown [57]. 


\section{Identification of EBV-Infected Cells in Their Tissue Context, Its Activity and Diagnostic or Therapeutic Approaches in Oncology}

Since latent EBV infection has been implicated in the pathogenesis of diverse malignancies, suitable test methods to evaluate gene integration and gene replication activity in EBV-infected cells are necessary to design proper biomarkers for diagnosis, disease progression and monitoring of treatment. Thus, the analysis of distinct EBV genomic regions, activation-associated gene products/proteins and antibody production following EBV infection is mandatory. Over the last decades, a number of different methods to identify EBV-related gene products and proteins in both blood and formalin-fixed, paraffinembedded (FFPE) tissue samples have been developed, which differ in terms of their significance and include serologic and molecular studies of EBV-associated gene products that predetermine the choice of the suitable detection method and are related to the clinical context $[60,69]$. It is noteworthy that the expression levels of certain EBV-specific genes determine the different latency types and are distinct in EBV-associated malignancies as summarized in Table 2.

\subsection{EBV-Encoded RNA Detection}

EBV-encoded RNA (EBER) in situ hybridization (ISH) is the "gold standard" for detecting and localizing EBV-infected cells in biopsy samples known to be the most sensitive method since EBERs are consistently expressed in all latent EBV infection types independent of their origin from neoplastic or morphologically normal tissues [60,70,71]. Although the application is widespread, there exist some limitations. While false-negative EBER hybridizations may result as a consequence of RNA degradation [72], false-positive EBER results may be attributable to latent infection of background lymphocytes or artifacts, such as non-specific staining or cross-reactivity with mucin, yeast or plant materials [72,73]. Thus, confirming the results by other diagnostic tools next to EBER-ISH increases the diagnostic accuracy.

\subsection{EBV-Specific DNA Detection}

Real-time polymerase chain reaction (PCR) is a fast and sensitive widely used method for evaluation of the virus load [74,75]. In detail, the quantification of episomal EBV DNA coding for EBNA-1 and the viral envelop glycoprotein (gp) 220 in the plasma and peripheral blood mononuclear cells (PBMCs) had to stand the test as a suitable marker of acute EBV infection that correlates with clinical symptoms [76,77]. In FFPE tissues, similar sensitivity and reliability of this method compared to EBER-ISH were shown, suggesting its use for EBV diagnostic screening [78]. It has to be taken into account that the viral load is higher in the oral cavity than in peripheral blood [79]. Considering this restriction as a quantitative tool, evaluation of the virus load helps to determine the severity of an EBV infection/reactivation and to identify patients with EBV-infection-related diseases. However, false-positive results in blood samples can be achieved due to the detection of EBV-positive memory cells, and therefore this method is not suitable to verify EBVassociated malignancies [78,80-82].

\subsection{Detection of $E B V$-Associated Biomarkers}

Latent EBV infections differ by their expression pattern of virus-coded proteins, which provides a diagnostic tool. Latency type 0 represents an antigen-negative form of infection only expressing EBER and BART miRs, while latency type I shows a selective expression of EBNA1. In latency type II, an expression of LMP-1, LMP-2A and LMP-2B is detectable. In addition, latency type III involves the expression of all six EBNA proteins $[2,60,73,83]$. Evaluation of the expression patterns in FFPE tissue samples can be easily assessed by immunohistochemistry (IHC) and ISH. In this context, evaluation of LMP-1 and EBNA-2 expression is an extremely simple and cost-effective tool to determine the latency types as demonstrated in Figure 1. 


\section{Latency type $0 / 1$ Plasmablastic lymphoma}

\section{Latency type 2 PTLD, polymorph}

\section{Latency type 3 infectious mononucleosis}
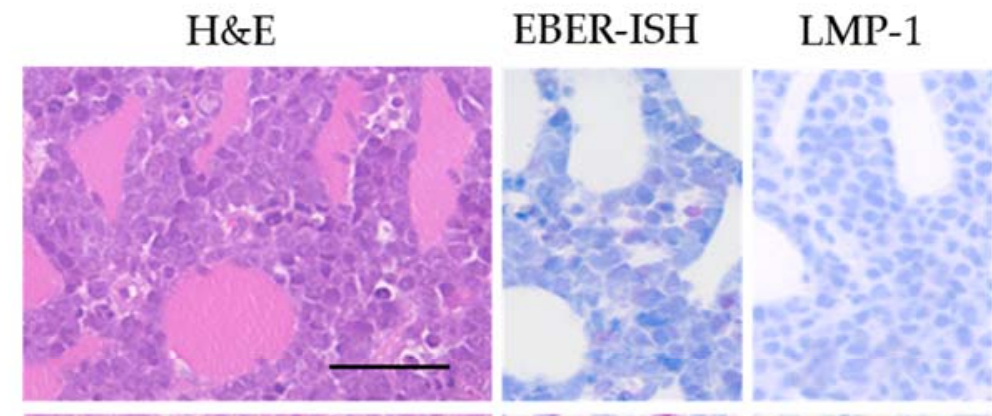

EBNA-2
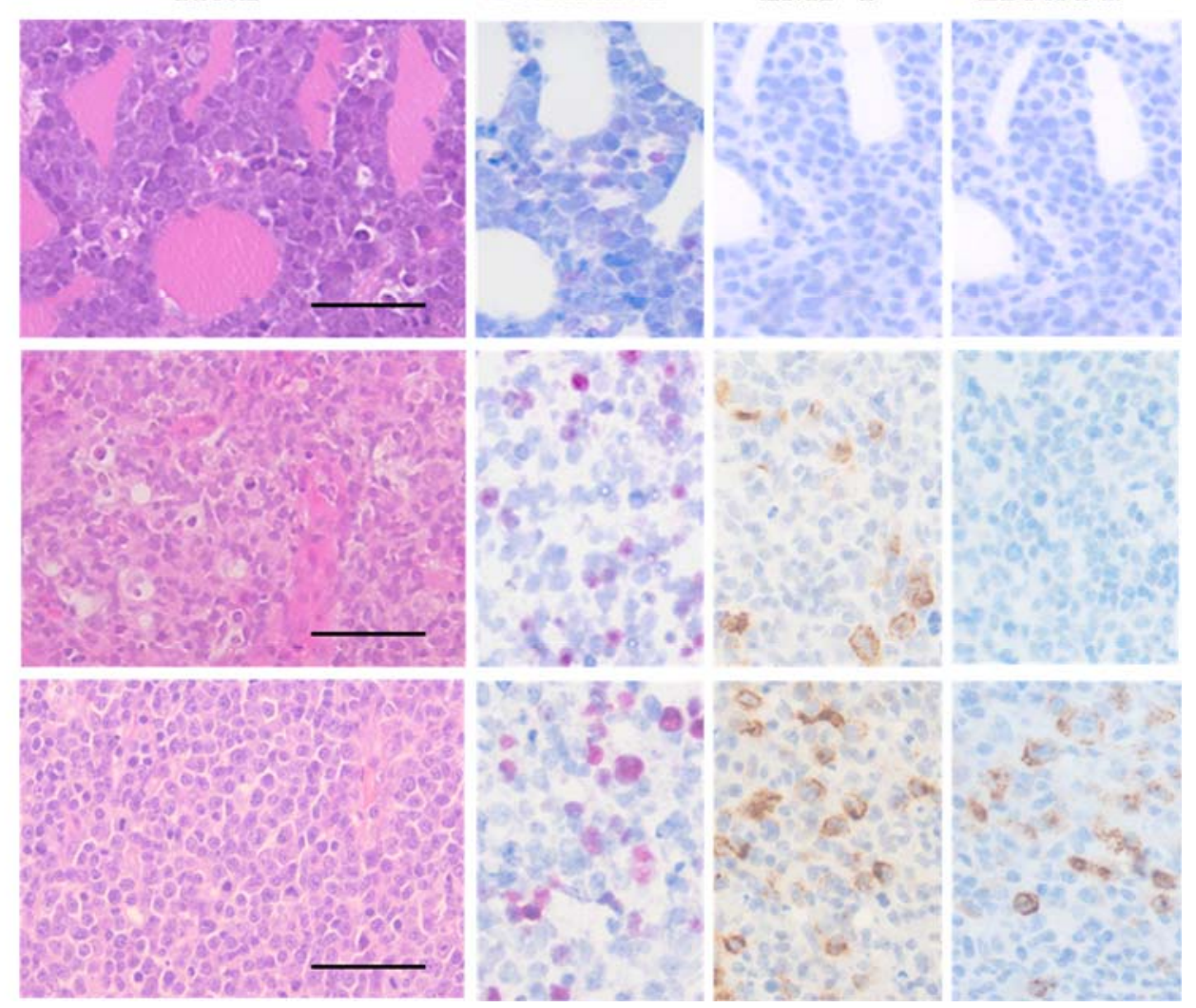

Figure 1. Micrographs of EBV-associated diseases using histopathological techniques. EBV latency type is correlated with EBV-associated diseases by using EBER-ISH and immunohistochemical stainings with antibodies against LMP-1 and EBNA-2. All latency types show positive signals in the EBER-ISH (pink nuclear signals). Plasmablastic lymphoma, latency type 0 or 1 , is negative for LMP-1 or EBNA-2. In contrast, the polymorphic PTLD exhibits positive signals for LMP-1 (brown membranous signal), while immunohistochemistry (IHC) for EBNA-2 remains negative. In infectious mononucleosis, all three markers are positive, and thus a latency type III is determined. H\&E stained micrographs show scale bars representing $50 \mu \mathrm{m}$.

\subsection{Detection of EBV-Specific Antibodies}

To evaluate the strength of the interaction between the virus and the host, various methods are available for serologic detection of antibodies against different structures of EBV. As a fast primary screening method, the heterophile antibody test detects subsets of antibodies produced by the human immune system in response to EBV infection. Specific immunologic tests include, e.g., enzyme-linked immunosorbent assay (ELISA), immunofluorescence assay, Western blot and IgG avidity assay as well as multiplex flow immunoassay $[84,85]$. Although displaying a high degree of variability, it is generally possible with this repertoire to define the individual infection status and to allow the distinction between acute, latent and reactivated infection. For screening, the viral capsid antigen (VCA) IgG, VCA IgM and EBNA-1 IgG are employed. The presence of VCA IgM and VCA IgG without EBNA-1 IgG correlates with acute EBV infection, whereas the presence of VCA IgG and EBNA-1 IgG without VCA IgM indicates a past infection. However, the interpretation of the serological findings can be difficult, since VCA IgG can be present without VCA IgM or EBNA-1 IgG in acute or past infection. In addition, all three parameters may be simultaneously detected upon acute or latent EBV infection [84]. No significant relationship between EBV serology and the presence of EBV in Hodgkin-Reed/Sternberg (HRS) was detectable in classical Hodgkin lymphoma (cHL) [86]. 


\subsection{Extracellular Vesicles (EVs) as Biomarkers for EBV-Associated Diseases}

Extracellular vesicles (EVs) are nanoparticles that can be released from EBV-infected cells and are membrane-surrounded structures. They are stratified by their size or their mechanisms of biogenesis and are classified into exosomes $(30-150 \mathrm{~nm})$, microvesicles $(100 \mathrm{~nm}-1 \mu \mathrm{m})$ and apoptotic bodies $(1-5 \mu \mathrm{m})$. EVs represent key factors of the intercellular cell-cell communication through the delivery of biologically active cargo containing a plethora of proteins, lipids, nucleic acids (e.g., miRs, IncRNAs, circRNA, DNA) and metabolites that can be taken up by distant cell types thereby affecting physiologic and pathophysiologic processes [87]. Thus, EVs are major players in cell growth, invasion, angiogenesis and immune cell regulation, which contribute to the development and progression of malignancies [88].

Recent advances in methods have facilitated the isolation of EVs, which are therefore in particular candidate biomarkers for liquid biopsies [89,90]. In this context, it was reported that EVs composed of different viral components including viral miRs (miRBARTs) and proteins are released from EBV-infected cells, which have profound effects on the cellular microenvironment [91]. Based on their cargo, EBV EVs play an important role in the regulation of EBV infection and the pathogenesis of EBV-associated diseases. The EBV oncoproteins LMP-1 and BARF1 were detected in EVs in the serum and saliva of NPC patients [92], which are also candidate biomarkers for NK/T cell lymphoma [93]. Thus, EVs might be helpful tools for diagnosis and prognosis as well as therapeutic targets in EBV-associated malignancies [94,95]. This is underlined by many efforts to create technical solutions to track EVs/exosomes with traceable markers for their use as potential biomarkers.

\section{Mechanisms of Latent-EBV-Infection-Induced Malignancies}

There exists a broad spectrum of malignancies following chronic latent EBV infection encompassing a couple of different cell types and anatomical localizations. For the distinct entities, EBV-associated versus non-EBV-associated malignancies differ regarding their gene expression profiles, metabolism, signal transduction and their immune escape mechanisms and the consecutive composition of the different players of the tumor microenvironment (TME) [52].

\subsection{Somatic Mutations}

In recent years, numerous genomic studies have been carried out demonstrating a higher mutational burden in EBV-positive compared to EBV-negative malignancies, which was even higher in type 1 compared to type 2 latency types [96]. It has been suggested that latent EBV gene and protein expression may contribute to genome instability in these tumors. In this context, LMP1 is known to impair the mitotic G2 checkpoint and lead to chromosomal instability by accumulation of somatic mutations [97], while other studies indicated that EBNA-1 may promote genomic instability [98]. EBNA-1 has been shown to act as a transcription factor thereby increasing the expression of cellular genes potentially important for oncogenesis [99]. Furthermore, EBNA-1 has been shown to promote DNA damage and genomic instability due to the generation of reactive oxygen species (ROS) [100]. Entity-independent somatic mutations following EBV infection and somatic mutations specific for EBV-associated hematologic malignancies or carcinoma are summarized in Table 3. As an example of entity-dependent mutations, alterations in the PI3K/AKT/MAPK signaling pathway, in particular in PIK3CA, are detected in EBV-associated NPC and GC but not in EBV-associated lymphoma [101-103].

In contrast, inactivating mutations or decreased protein expression of ARID1A encoding a member of chromatin-remodeling proteins were detected in both EBV-associated carcinoma and lymphoma $[102,104,105]$. However, it is noteworthy that ARID1A aberrations were reported in EBV-associated as well as in EBV-negative GC subtypes [106]. Lower frequencies of TP53 mutations that usually show a positive correlation with higher mutational burden have been reported for EBV-positive NPC, GC, BL and PTLD [105,107-111] despite that the 
p53 pathway is frequently deregulated in these diseases [110]. As an exception, no correlation between TP53 mutations and EBV status was found in cHL [112]. Deciphering the mutational landscape of EBV-associated malignancies provided new insights into their tumorigenesis and elucidated the mechanisms of how EBV-induced malignancies manipulate the immune system. These issues are described in Sections 4.3 and 4.4, respectively.

Table 3. Genetic landscape of EBV-associated malignancies. ( $\downarrow$ : down in EBV-associated malignancies, $\uparrow:$ up in EBVassociated malignancies).

\begin{tabular}{|c|c|c|c|c|c|}
\hline Function & Gene & $\begin{array}{c}\text { Type of Genetic } \\
\text { Aberration }\end{array}$ & $\begin{array}{l}\text { Frequency in } \\
\text { EBV-Associated } \\
\text { Malignancies }\end{array}$ & $\begin{array}{l}\text { EBV-Associated } \\
\text { Malignancies }\end{array}$ & References \\
\hline DNA repair & TP53 & Inactivation & $\downarrow$ & $\begin{array}{l}\text { NPC, GC, BL, } \\
\text { PTLD }\end{array}$ & $\begin{array}{c}{[104,105,109-} \\
111,113]\end{array}$ \\
\hline \multirow{3}{*}{$\begin{array}{l}\text { Signal } \\
\text { transduction }\end{array}$} & PIK3CA & Inactivation & $\uparrow$ & NPC, GC & [101-103] \\
\hline & PIK3R1 & Inactivation & $\uparrow$ & GC & [102] \\
\hline & SMAD4 & Inactivation & $\uparrow$ & GC & [102] \\
\hline $\begin{array}{l}\text { Chromatin } \\
\text { remodeling }\end{array}$ & ARID1A & Inactivation & $\uparrow$ & NPC, GC, & {$[102,104,105]$} \\
\hline $\begin{array}{c}\text { Transcription } \\
\text { factor }\end{array}$ & MYC & Activation & $\downarrow$ & BL & [105] \\
\hline \multirow{2}{*}{ IFN signaling } & JAK2 & Amplification & $\uparrow$ & GC & [103] \\
\hline & SOCS1 & Mutation & $\downarrow$ & GC, PTLD & [111] \\
\hline \multirow{3}{*}{ NF-kB pathway } & TRAF3 & Inactivation & $\uparrow$ & NPC & [114-116] \\
\hline & CYLD & Inactivation & $\uparrow$ & NPC & [114-116] \\
\hline & NF-kBIA & Inactivation & $\uparrow$ & NPC & [114-116] \\
\hline $\begin{array}{c}\text { Antigen } \\
\text { presentation }\end{array}$ & MHC-I & Inactivation & $\uparrow$ & NPC & [116] \\
\hline
\end{tabular}

\subsection{Epigenetic Alterations}

EBV infection is an epigenetic driver and massively alters the gene signature and gene regulation in infected host cells. The main mechanisms in EBV-associated malignancies encompass altered DNA methylation and histone acetylation.

DNA hypermethylation of genes has been described in various diseases [52]. Global DNA methylation changes toward increased $\mathrm{CpG}$ island hypermethylation were found in human immortalized normal oral keratinocytes after EBV infection [117] and also in EBVassociated malignancies [118]. Thus, DNA methylation affects both the host and the EBV genome. The expression of different virus-encoded genes in infected host cells is strictly controlled by DNA methylation of viral promoter $\mathrm{CpG}$ islands, which is a prerequisite for the different phases of the viral life cycle [119]. Genes predominantly involved in the lytic phase are regulated by promoter hypermethylation leading to their repression. The targeting of such epigenetically repressed promoter regions by BZLF1 gene product Zta reverses their silencing and enhances the expression of genes required for the lytic phase [119]. Next to EBV-positive GC, exhibition of an extremely high DNA methylation pattern was also shown in EBV-positive lymphoma and NPC specimens. NPC-derived cell lines exert hypermethylation of the EBV transcription start sites when compared to non-malignant corresponding EBV-infected human tissues [120]. These data are in line with a study comparing seven EBV-positive NPC lesions and five non-cancer nasopharyngeal epithelium tissues regarding the methylation status of seven candidate genes with known hypermethylated promoter $\mathrm{CpG}$ islands and reduced expression in NPC tissues, such as CR2, ITGA4, RERG, RRAD, SHISA3, ZNF549 and ZNF671, demonstrating significantly higher methylation rates of these genes in NPC than in control tissues [114]. In contrast, 
a clinical study of EBV-positive and EBV-negative HL patients investigating a panel of seven selected tumor-associated human genes known to be hypermethylated in various malignancies (RASSF1A, P16, CDH1, DAPK, GSTP1, SHP1 and MGMT) demonstrated that the promoters of these genes were more frequently hypermethylated in EBV-negative than in EBV-positive cases [121]. Furthermore, there might exist a competition of DNA methylation between different host DNA sequences and EBV DNA sequences. This is underlined by the fact that the EBV genome could be a target of the human DNA methyltransferases (DNMTs) since the RNAi-mediated DNMT1 and DNMT3B depletion resulted in a hypomethylation of CpG sites in the EBV genome [120]. So far, only a limited number of in vitro and in vivo studies with small cohort sizes and even using different methods for DNA methylation analyses are available.

Another important epigenetic mechanism regulating gene expression is the alteration of histone acetylation. Histone acetylation enables gene transcription by assessing the DNA locus via changes in the chromatin structure, whereas histone deacetylation leads to the suppression of gene transcription [122]. In an in vitro study, the treatment of Raji cells with the histone deacetylase inhibitor trichostatin A resulted in a minor BZLF1 induction [123]. However, distinct EBV-positive cell lines exhibited varying sensitivities when treated with different histone deacetylase inhibitors resulting in a lytic activation induced by BZLF1 and BRLF1 [124].

\subsection{Tumor Microenvironment}

The TME plays a central role in local cancer control by recruiting and differentiating immune-suppressive and/or anti-inflammatory cells, such as regulatory $\mathrm{T}$ cells (Tregs), Th17 cells, dendritic cells (DCs), M2 tumor-associated macrophages (TAMs) and myeloidderived suppressor cells (MDSCs), and inhibiting immune effector cells such as NK cells and $\mathrm{CD}^{+} \mathrm{T}$ lymphocytes, which leads to the establishment of an immunosuppressive TME [125]. Next to neoplastic properties, it has been known for decades that EBV infection can influence the composition and function of the TME consisting of both innate and adaptive immune cells, different soluble factors and EVs, which depend on the EBVassociated malignancies (Figure 2) [126-130]. In EBV-driven malignancies, the TME is modulated for viral benefit, thereby affecting disease progression. After infection, EBV can regulate its own viral and non-viral protein expression within the host cell and, in case of malignancies, actively modulate the tumor phenotype and in turn the tumor/TME interaction [131]. Although highly variable, the density of lymphocytes and plasma cells within the tumor stroma and of EBV-associated malignancies is elevated when compared to EBV-negative neoplasia as seen in other virus-associated tumors [132,133]. Furthermore, multiple viral infections within the same tumors could influence the TME [105]. However, some characteristics are more common between EBV-associated tumors compared to EBV-negative counterparts, which do not depend on the anatomical localization or cellular origin $[23,114,126-130,134,135]$. It is noteworthy that for some EBV-associated diseases only a little information on the TME is available due to their low incidence, such as NK/T cell lymphoma. Over the last years, the TME of EBV-positive NPC and GC was extensively investigated and demonstrated an unusual lymphocyte-rich stroma [136-138]. In contrast, in EBV-positive lymphomas and lymphoproliferative diseases, the impact of viral infection on the TME is not so evident and viral infection was rather assigned a predominantly oncogenic role [1,139-142]. Since the effects of EBV on the TME of EBV-associated malignancies is broad, this review focuses on the differences in the composition of the cellular and soluble components of the TME in both EBV-positive and EBV-negative malignancies. 


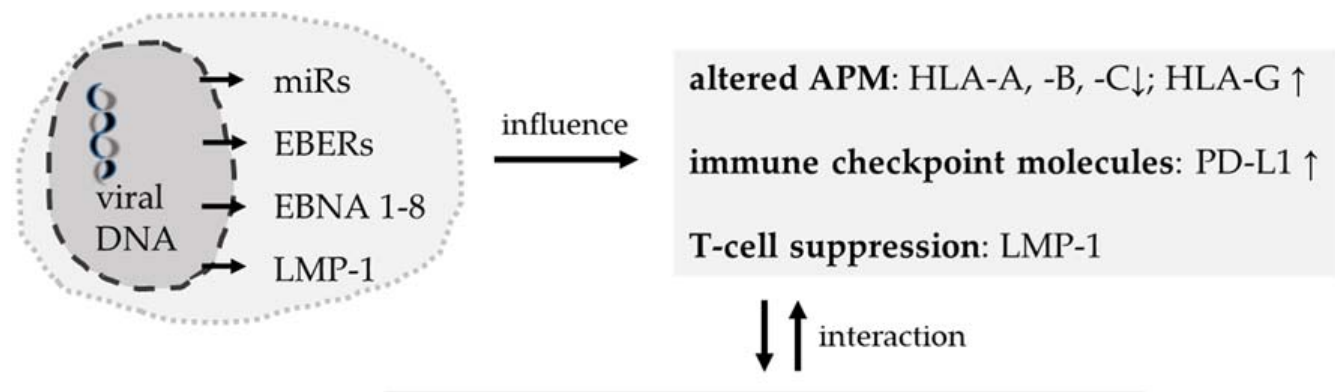

altered TME in EBV-positive tumors

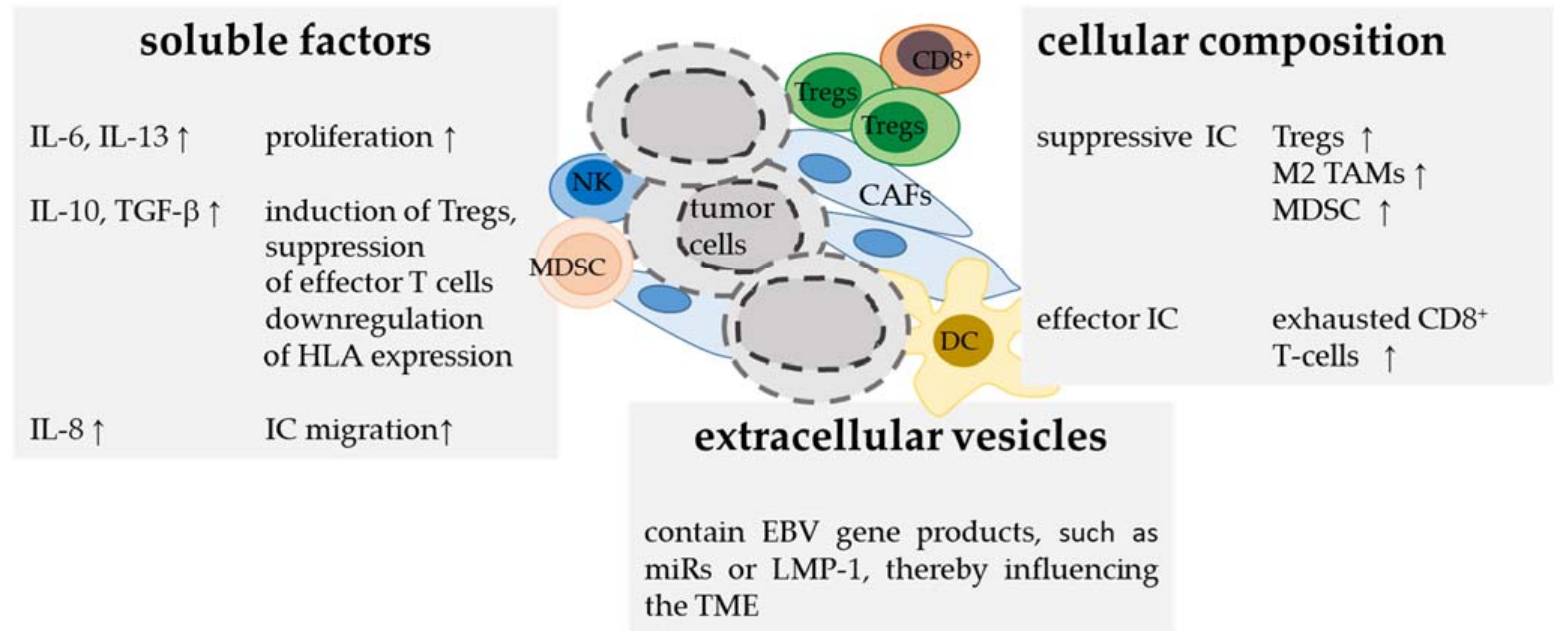

Figure 2. Composition of the TME in EBV-positive tumors. EBV gene products influence innate and adaptive immunity and thereby modulate the TME. Latent membrane protein (LMP) 1 suppresses the function of effector T cells and can be presented by tumor cells, extracellular vesicles or antigen-presenting cells (APCs) such as dendritic cells (DCs) via human leukocyte antigen (HLA) class II molecules. In addition, EBV-genome-related miRs influence the HLA class I antigen processing machinery (APM). Other strategies of the tumor cells to escape the immune surveillance are upregulation of non-classical HLA-G and/or immune checkpoint molecules, such as the programmed death ligand-1 (PD-L1). Furthermore, EBV-positive tumors induce a highly variable composition of the TME with increased numbers of different immune cell subsets, in particular high frequencies of effector T cells, regulatory T cells (Treg) and M2-polarized macrophages. It has been shown that soluble factors, secreted by tumor cells, cancer-associated fibroblasts (CAFs) or even other immune cells (ICs) promote immune cell migration into the TME. Furthermore, soluble factors such as interleukin-10 (IL-10) can induce Tregs, suppress effector T cells and regulate HLA class I expression.

\subsubsection{Cellular Composition of the TME}

The immune cell composition of the TME, which is modulated by the expression of interleukins (ILs) and chemokines, partially overlaps between EBV-positive and EBVnegative malignancies $[143,144]$. Despite the high diversity, some features could be even linked to EBV-positive lymphoproliferations and lymphomas. By comparing the TME of different lymphoma entities, such as EBV-positive BL, DLBCL and cHL, a few similarities of the immune cell repertoire exist, which are not only based on the histomorphology. A main feature of cHL is the predominance of bystander immune cells with only a sparse presence of neoplastic Hodgkin-Reed/Sternberg cells, and thus it presents a unique pattern of a surrounding immune ecosystem [145]. In contrast, the malignant cells in BL and DLBCL represent the largest proportion within the tissue, and the non-neoplastic immune cells represent the minority of cells $[146,147]$. Despite these features, common characteristics between EBV-associated malignancies exist including high levels of tumor-infiltrating lymphocytes (TILs) within the TME [23,114,126-130]. Not only the amount of TILs is higher in EBV-positive tumors, but also the proportion of the different immune cell subpopulations within the TME varies. For example, the number of $\mathrm{CD}^{+} \mathrm{T}$ cells and M2-polarized 
tumor-associated macrophages (TAMs) is increased in both EBV-positive carcinoma and lymphatic malignancies including cHL, BL and DLBCL [23,130,131,145,148,149]. Higher numbers of $\mathrm{CD}^{+} \mathrm{T}$ cells are associated with an increased frequency of effector $\mathrm{T}$ cells expressing the cytotoxic molecules TIA and granzyme (gran) B and a reduced expression of the WNT and TGF- $\beta$ pathway signature [114]. Recently, single-cell sequence analysis of $\mathrm{CD}^{+} \mathrm{T}$ cells from both the TME and the peripheral blood of EBV-positive NPC identified high numbers of exhausted $\mathrm{CD}^{+} \mathrm{T}$ cells, which in turn also contribute to a reduced cytotoxic activity $[150,151]$. In different EBV-positive tumor types, such as NPC [150,151], BL [145], DLBCL [152,153] and cHL [154], a significantly more restricted T-cell receptor (TCR) repertoire was found when compared to that of EBV-negative malignancies. T-cell exhaustion represents one of the most prominent strategies of tumors to circumvent the anti-tumor immune responses, but the underlying mechanisms of this phenomenon remain largely unknown [155].

Furthermore, the frequency of $\gamma \delta \mathrm{T}$ cells in patients with EBV-positive NPC was unaltered but showed an impaired T-cell function characterized by reduced cytotoxicity for the NPC targets [156]. In addition, a higher frequency of Tregs was shown in some EBV-associated malignancies [157-160], while Tregs are only poorly represented in BL [145]. Tregs are potent suppressors of other immune cells and can create an immunosuppressive environment [160]. In some EBV-positive malignancies, lower frequencies of CD8 ${ }^{+} \mathrm{T}$ cells as well as of other effector immune cells, such as NK cells and M1 macrophages, were found $[158,160]$.

Concerning TAMs, increased numbers of $\mathrm{CD}_{163}{ }^{+} \mathrm{M} 2$ TAMs [130] known to be involved in tumor progression and immune-suppressive functions were detected in almost all EBV-associated malignancies $[130,145,149]$ and were mainly distributed in the stroma. In addition, myeloid-derived suppressor cells (MDSCs) with immune regulatory properties are expanded in EBV-positive tumors, such as NPCs [161], and have a potent immunesuppressive activity sustaining an anti-inflammatory TME by suppressing T-cell effector functions $[150,162]$. Next to their presence in the stroma, circulating MDSCs were detected in the PBMCs of HL, NPC and GC patients [163-165]. Cancer-associated fibroblasts (CAFs) generally surround tumor cells, in particular NPC, but with a variable extent and were also found in EBV-positive GC [166,167]. Upon stimulation, CAFs produce pro-inflammatory cytokines thereby creating a tumor-supportive micromilieu. Furthermore, the interplay of the suppressive immune cell subpopulations of the TME of EBV-positive tumors can strongly suppress the activation of effector T cells. This is also attributed to the effects of the EBV-encoded LMP-1 protein that is expressed in many tumor cells of EBV latency type II and III [148]. Despite that NK cells play a major role in anti-tumor immune responses, there exists only limited information in EBV-associated malignancies. An increased frequency of NK cells was found in the TME of EBV-positive HL [157] in association with the induction of tumor-suppressive pathways [168,169]. Furthermore, NPCs are highly infiltrated by NK cells with impaired function mitigated by elevated IL-18 levels, which was correlated with a worse patient prognosis $[170,171]$. In addition, the frequency of CD57 ${ }^{+} \mathrm{NK}$ cells is higher in EBV-infected than in EBV-negative GC, related to patients' age, tumor diameter and PD-L1 expression [172] and linked to high tumoral IFN- $\gamma$ levels [173]. NK cells are part of the innate immune response against EBV and have an important function during primary infection [174].

So far, the role of B cells in the TME of EBV-positive malignancies has been postulated by some authors, but this is controversially discussed. In the majority of EBV-associated malignancies, B-cell infiltration was found, but with a lower frequency when compared to T cells. In NPC, B-cell frequency highly varies with lower B-cell frequencies in one report [151] but higher frequencies in another study [150]. So far, there exist no investigations focusing on B-cell subpopulations including differences regarding EBV-positive or EBV-negative reactive B cells within the TME and their influence on the composition and functional condition. It is noteworthy that the altered immune cell composition in EBV-associated diseases is accompanied by a distinct patient outcome that is discussed 
in Section 4.5. The immune cell subpopulations, their differential regulation within the TME, the expression of immune-modulatory molecules and the clinical significance are summarized in Table 4.

Table 4. Differences of the frequency of immune cell subpopulations in the TME in EBV-positive vs. EBV-negative malignancies and their clinical significance. Abbreviations: DC: dendritic cell; n.a. not available; NK cell, natural killer cells; TAM, tumor-associated macrophage; TIL, tumor-infiltrating lymphocyte; Treg, regulatory T cell.

\begin{tabular}{|c|c|c|c|c|}
\hline Disease & $\begin{array}{c}\text { Immune } \\
\text { Populations/Markers }\end{array}$ & EBV+ vs. EBV- & Clinical Significance & Reference \\
\hline \multirow{7}{*}{ NPC } & TILs & higher & good prognosis & {$[114,128]$} \\
\hline & $\mathrm{CD}^{+} \mathrm{T}$ cells & higher & good prognosis & {$[114,150]$} \\
\hline & exhausted T cells & more frequent & n.a. & {$[151,175]$} \\
\hline & Tregs & higher & n.a. & {$[150,160]$} \\
\hline & B cells & higher & better prognosis & {$[114,150]$} \\
\hline & $\mathrm{LAMP3}^{+} \mathrm{DC}$ & higher & n.a. & [150] \\
\hline & M2 TAM & high & poor survival & [149] \\
\hline \multirow{4}{*}{ GC } & TILs & higher & increased survival & {$[127,176]$} \\
\hline & $\mathrm{CD}^{+} \mathrm{T}$ cells & higher & increased survival & {$[127,177]$} \\
\hline & $\mathrm{CD}^{+} \mathrm{T}$ cells & higher & increased survival & {$[177,178]$} \\
\hline & DCs & higher & $\begin{array}{l}\text { correlation of some DC } \\
\text { subsets with a worse } \\
\text { survival }\end{array}$ & [179] \\
\hline \multirow{2}{*}{ ICC } & $\mathrm{CD}^{+} \mathrm{T}$ cells & higher & good prognosis & [23] \\
\hline & CD20 B cells & higher & good prognosis & [23] \\
\hline \multirow{4}{*}{ cHL } & $\mathrm{CD}^{2} 6^{+} \mathrm{CD} 16^{+} \mathrm{NK}$ cells & higher & n.a. & [157] \\
\hline & FoxP3 $^{+}$Tregs & increased & worse prognosis & [180] \\
\hline & exhausted T cells & more frequent & n.a. & [154] \\
\hline & M2 TAM & higher & worse survival & [181] \\
\hline \multirow{3}{*}{ PTLD } & $\mathrm{CD}^{+} \mathrm{T}$ cells & high & none & [158] \\
\hline & Tregs & high & n.a. & [158] \\
\hline & TAM & high & & [182] \\
\hline \multirow[t]{2}{*}{ DLBCL } & TCR repertoire & $\begin{array}{l}\text { increased highly } \\
\text { dominant clones }\end{array}$ & worse survival & {$[152,153]$} \\
\hline & M2 TAM & high & worse survival & [130] \\
\hline \multirow{3}{*}{ BL } & $\mathrm{CD}^{+} \mathrm{T}$ cells & higher & n.a. & [145] \\
\hline & exhausted T cells & more frequent & n.a. & [145] \\
\hline & M2 TAM & high & n.a. & [145] \\
\hline
\end{tabular}

\subsubsection{Soluble Mediators}

An aberrant chemokine and cytokine expression directly affects the above-mentioned composition of the TME, and these soluble mediators have been shown to be involved in EBV-mediated malignancies. Relevant ILs and chemokines, their regulation and function in the tumor progression and local immune regulation of EBV-positive tumors are summarized in Table 5. In particular, the local secretion of pro-inflammatory ILs and chemokines influences the functionality of the immune cells and thus modulates tumor progression (Table 5) $[183,184]$. It can be assumed that alterations in these soluble mediators precede immune cell infiltration. 
Table 5. Altered cytokine and chemokine expression pattern, their functional relevance and detection methods in EBVassociated malignancies.

\begin{tabular}{|c|c|c|c|c|c|}
\hline Interleukin & Origin & Regulation & Function & $\begin{array}{l}\text { Detection } \\
\text { Methods }\end{array}$ & Reference \\
\hline IL-1ß & $\begin{array}{l}\text { predominantly } \\
\text { secreted by } \\
\text { monocytes and } \\
\text { macrophages }\end{array}$ & upregulation & inflammation & IHC, FFPE tissues & [185] \\
\hline IL-4 & $\begin{array}{l}\text { predominantly } \\
\text { secreted by Th2 } \\
\text { cells, mast cells, } \\
\text { NKT cells, } \\
\text { basophils and } \\
\text { eosinophils }\end{array}$ & upregulation & cell growth & RNA, PBMNCs & [38] \\
\hline IL-6 & $\begin{array}{l}\text { predominantly } \\
\text { secreted by } \\
\text { monocytes, } \\
\text { macrophages, T/B } \\
\text { cells, neutrophils, } \\
\text { endothelial cells, } \\
\text { fibroblasts, } \\
\text { adipocytes }\end{array}$ & upregulation & $\begin{array}{l}\text { cell growth, } \\
\text { Th17 } \\
\text { differentiation }\end{array}$ & $\begin{array}{l}\text { IHC FFPE tissue, } \\
\text { WB; ELISA: cell } \\
\text { culture }\end{array}$ & [186-188] \\
\hline IL-8 & $\begin{array}{l}\text { predominantly } \\
\text { secreted by } \\
\text { monocytes and } \\
\text { macrophages }\end{array}$ & upregulation & cell migration & IHC, FFPE tissue & [189] \\
\hline IL-10 & $\begin{array}{l}\text { predominantly } \\
\text { secreted by } \\
\text { regulatory T cells, } \\
\text { macrophages, DCs } \\
\text { and neutrophils } \\
\text { but also Th2 cells } \\
\text { and Th17 cells }\end{array}$ & upregulation & $\begin{array}{l}\text { immunosuppression, } \\
\text { downregulation of } \\
\text { MHC class I, } \\
\text { induction of Treg }\end{array}$ & $\begin{array}{l}\text { ELISA: PMBC cell } \\
\text { culture }\end{array}$ & [185,188,190-192] \\
\hline IL13 & $\begin{array}{l}\text { predominantly } \\
\text { secreted by Th2 } \\
\text { cells, mast cells, } \\
\text { basophils }\end{array}$ & upregulation & cell growth & ELISA: cell culture & [193] \\
\hline IFN- $\gamma$ & $\begin{array}{l}\text { predominantly } \\
\text { secreted by NK } \\
\text { cells, CTLs, Th1 } \\
\text { cells }\end{array}$ & upregulation & inflammation & IHC: FFPE tissue & [185] \\
\hline IP-10 (CXCL10) & $\begin{array}{l}\text { predominantly } \\
\text { secreted by } \\
\text { monocytes and } \\
\text { macrophages but } \\
\text { also by endothelial } \\
\text { cells }\end{array}$ & upregulation & $\begin{array}{l}\text { inflammation, } \\
\text { chemotaxis }\end{array}$ & $\begin{array}{l}\text { RNA: cell culture, } \\
\text { tumor tissue; ISH: } \\
\text { FFPE tissue }\end{array}$ & [194-196] \\
\hline SDF-1, CXCL12 & $\begin{array}{l}\text { predominantly } \\
\text { secreted by } \\
\text { macrophages and } \\
\text { adipose tissue but } \\
\text { also by } \\
\text { cancer-associated } \\
\text { fibroblasts }\end{array}$ & upregulation & $\begin{array}{l}\text { inflammation, } \\
\text { chemotaxis, cell } \\
\text { growth }\end{array}$ & $\begin{array}{c}\text { IHC: FFPE tissue; } \\
\text { flow cytometry: } \\
\text { PBMC }\end{array}$ & [197-199] \\
\hline
\end{tabular}


Studies of both solid and hematological EBV-associated malignancies demonstrated higher levels of IL-10 expression compared to EBV-negative malignancies in the same anatomical region or the same cells of origin [200-204], which are linked to local immune suppression or local enhanced immune cell tolerance [205]. In fact, IL-10 is known to (i) downregulate the expression of major histocompatibility complex (MHC) class I and II antigens of antigen-presenting cells (APCs) [191], (ii) induce Tregs [190], which in turn (iii) inhibit T-cell proliferation and IFN- $\gamma$ secretion [192], and (iv) functionally block cytotoxicity of $\mathrm{CD}^{+} \mathrm{T}$ cells [188] causing an immune-suppressive TME. Furthermore, in vitro knockdown of IL-10 switches latent EBV-infected tumor cells to the lytic form leading to tumor cell death. This also synergizes with chemotherapy and thus leads to cell death [206] suggesting that IL-10 exhibits a key role in EBV-positive malignancies. Furthermore, IL-4, IL-6 and IL-13 are frequently upregulated in EBV-positive malignancies and might have relevance in the development and/or maintenance of EBV-associated malignancies $[188,207,208]$. Regarding IL- $1 \beta$, increased levels were found in the TILs of EBV-positive GC [185]. Higher levels of IL-6 are present in both epithelial and lymphoid EBV-positive neoplasms acting as a growth factor [186-188]. In addition, IL-6 promotes Th17 differentiation, which is linked to autoimmunity, while their role in the context of malignancies is still controversially discussed [209]. Notably, tumor tissues frequently show a considerable infiltration of $\mathrm{CD}^{+} \mathrm{T}$ cells, which may act as a source of these cytokines [158]. Moreover, the IFN- $\gamma$-induced protein 10 (IP-10, CXCL10) is upregulated in several EBVpositive tumors, such as cHL, NPC and GC. The expression of IP-10 in the TME can attract a variety of immune cells, e.g., monocytes, T cells and NK cells $[195,210]$. In EBV-positive GC, IP-10 is linked to better survival $[194,196,199]$. Another frequently upregulated soluble mediator is the stromal cell-derived factor-1 (SDF-1, CXCL12) known to initiate chemotaxis and promote cell growth [197-199]. CAFs have been shown to secrete high levels of SDF-1/CXCL12 in different cancer types including EBV-positive NPCs [198,211-213]. In line with the increased expression of SDF-1/CXCL12, an upregulated expression of the associated chemokine receptor CXCR4 was also detected on EBV-positive NPC, GC and B-cell lymphomas [197,214,215].

\subsubsection{Extracellular Vesicles in EBV Infection and Persistence}

As outlined above, EVs/exosomes released from EBV-infected cells have been shown to contain a variety of bioactive molecules [216] and may affect the phenotype of recipient cells depending on the cargo transmitted, thereby influencing the tumor progression [217]. In general, exosomes are able to stimulate immune responses by acting as antigen-presenting vesicles [218,219]. EBV-positive tumor cells can release EBV-encoded RNAs, EBER1, EBER2, miRNAs and the LMP-1 protein via exosomes allowing the RNAs and / or proteins to be captured by EBV-negative bystander cells, such as follicular DCs, and can then be presented by these APCs to other EBV-negative immune cells thereby inhibiting their activation [220]. In addition, exosomes of EBV-positive cancer cells can modulate the function of stromal cells, inhibit DC maturation in vivo and exhibit T-cell inhibitory activity $[179,221,222]$ (see also Figure 2).

\subsection{Immune Escape of EBV-Infected Cells}

It has been well established that cells of the innate and adaptive immune system are able to recognize and eliminate cancer cells. However, the processes of malignant and/or viral transformation, as well as increased growth, are associated with strategies of tumor cells to escape immune surveillance [223] by evading the immune surveillance and/or by suppressing the hosts' immune system mediated by shaping the TME and dampening the effector function $[224,225]$. Indeed, tumor cells can convert immune cells to a tolerogenic and dysfunctional state due to cell-cell interactions, soluble mediators and physical factors in the TME. In order to allow the establishment of infection and persistence, EBV has adopted different strategies to modulate signaling pathways to minimize their anti-viral activity while taking the advantage of their growth-promoting effects to circumvent host 
immune responses and to compromise innate and adaptive immunity during the latent and replicative phase of its life cycle [226]. The immune escape mechanisms are broad and include prevention of apoptosis induction, EBV-enhanced cell proliferation and inhibition of immune recognition of EBV-infected cells by latent or lytic EBV-encoded gene products and/or non-coding viral RNAs. These factors contribute to the disease prognosis and prediction of therapy response thereby exerting a clinical relevance [126]. Interestingly, there exist similarities but also differences between the immune escape strategies of solid and hematopoietic EBV-associated tumors $[143,224]$.

A number of EBV gene products and miRs have been identified during the last decades to be involved in immune escape mechanisms of EBV-associated malignancies. The functions of the key molecules in the immune escape are addressed in this section in more detail (Table 6).

\subsubsection{Distinct Genetic Alterations of Immune-Modulatory Molecules}

Some structural and epigenetic peculiarities have been described in EBV-positive malignancies, which represent molecular heterogeneous diseases, and were associated with immune escape mechanisms. A higher burden of genomic alterations in genes involved in immune signaling pathways, such as the JAK/STAT pathway (e.g., chromosomal gains of JAK2) $[227,228]$ or the antigen presentation machinery (APM), has been identified. The latter include inactivating mutations and structural variants in the MHC class I genes, APM components $\left(\beta_{2}-\mathrm{M}, \mathrm{TAP} 1\right)$ and the transcription factor NLRC5 known as the regulator of the expression of APM components, which are very common in EBV-positive NPC and $\mathrm{NK} / \mathrm{T}$ cell lymphomas $[116,229]$. In contrast, genetic alterations of HLA class II genes are not frequently detected.

Loss-of-function mutations in negative regulators of the NF-kB pathway including TRAF3, CYLD and NFKBIA with consecutive increased NF-kB activation were detected in particular in NPC [104,115]. Furthermore, a high frequency of PD-L1/PD-L2-involving genetic aberrations, such as PD-L1/PD-L2 amplifications at chromosome 9p24.1, was demonstrated in EBV-positive B- and T-cell lymphoma but also in NPC [230].

\subsubsection{Downregulation of HLA Class I and Class II Surface Antigens}

Next to structural alterations of HLA class I antigens, a frequently observed mechanism enabling immune evasion is the downregulation of components involved in the antigen presentation mediated by HLA class I. Many gene products of the APM are known to be transcriptionally induced by cytokines, especially by IFN- $\alpha$, IFN- $\gamma$ and TNF- $\alpha$, while they are reduced by TGF- $\beta$ and IL-10 and/or post-transcriptionally regulated by miRs $[231,232]$. In the context of EBV-associated malignancies, the expression of HLA class I APM can be influenced by host as well as EBV gene products. Several EBV-encoded molecules have been identified to directly interfere and reduce proper antigen presentation of EBV-infected cells. These include EBV-encoded proteins and miRs. EBV-encoded gene products expressed in the early or late lytic phase of EBV infection, such as BGLF5, BNLF2A and BILF1, downregulate the HLA class I antigen presentation [233-237]. Recently, multiple conserved residues in the extracellular regions have been shown to be important for the BILF1-mediated downregulation of HLA class I antigens [238]. EBNA-1 disrupts the peptide generation and their transport for functional presentation on HLA class I molecules [239], while BNLF2 interferes with the functionality of the peptide transporter (TAP)1 subunit $[240,241]$, which is required for the peptide transport into the ER for peptide loading onto HLA class I molecules. In the prelatent phase, EBNA2 and lytic gene products are expressed [242], which prevent accurate peptide generation, transport and loading onto HLA class I molecules and thus impair the presentation of viral antigens toward CD8 ${ }^{+} \mathrm{T}$ cells able to distinguish between self- and non-self-antigens [243]. Peptide presentation is also negatively regulated by virus-encoded miRs, in particular, EBV-miR-BART17 and the three EBV-miR-BHRF1-3 [244]. Not only HLA class I but also HLA class II antigens could be affected by EBV infection. Gp42 known as an entry receptor of EBV has immune- 
suppressive properties, since both membrane-bound and soluble Gp42 block HLA class II antigen presentation, while BGLF5 degrades HLA class II [245-247]. Furthermore, Zta1 expression caused downregulation of HLA class II expression via inhibition of CIITA [248].

Concerning host gene expression, an upregulation of host miRs targeting components involved in the HLA class I antigen presentation pathway, so-called immune-modulating miRs have been identified [231,232]. The induced expression of host and/or virus-encoded immune-suppressive anti-inflammatory cytokines, such as IL-10 or the viral interleukin-10 (vIL-10), which is encoded by the EBV BCRF1 gene $[249,250]$, downregulates the peptide presentation resulting in an inhibition of immune effector cells [251].

\subsubsection{Upregulated Expression of Non-Classical HLA Class I Antigens}

In addition to classical HLA class I molecules, the non-classical HLA-G, HLA-E and HLA-F antigens not only present peptides but also represent ligands to inhibitory receptors of immune effector cells and mediate, under physiological conditions, the immunological tolerance of immune-privileged tissues, such as cornea, testis and chorion [252]. The HLAG binds to the inhibitory receptors ILT2, ILT4 and KIR2DL4 that are expressed on different immune cell subsets such as NK cells, T cells, B cells or monocytes thereby representing an important immune escape mechanism [253]. So far, little information exists regarding the role of non-classical antigens upon EBV-driven malignant transformation. Interestingly, EBV infection can induce HLA-G [254], which is accompanied by an induction of IL-10 known to enhance HLA-G expression [255]. Furthermore, HLA-G is expressed in cHL and has been suggested as a potential immune escape mechanism in this disease [256]. HLA-E binds to the inhibitory receptors CD94/NKG2A and CD94/NKG2B and to the activating receptor NKG2C $[257,258]$. EBV-derived peptides have been detected to be presented by HLA-E molecules and to stabilize their surface expression [259]. In addition, HLA-F can be induced upon EBV-mediated transformation of lymphoblastoid cell lines [260]. In contrast, EBV-encoded proteins or miRs altering the expression of HLA-G, -E and -F in EBV-associated malignancies have not yet been identified.

\subsubsection{Increased Expression of Checkpoint Molecules}

Next to HLA antigens, immune-modulatory cell surface proteins also exhibit a distinct expression pattern in EBV-positive tumors. Regarding immune checkpoints, such as the programmed death-1 receptor (PD-1) and its programmed death ligand-1 (PD-L1) and PD$\mathrm{L} 2$, which represent one prominent mechanism to escape immune surveillance, an increased PD-L1 expression was detected in EBV-positive when compared to EBV-negative specimens from NPC [139], gastric cancer [261], DLBCL and cHL [183,262], respectively. PD1 and CTLA-4 are upregulated on EBV-infected T cells, and PD-L1 expression is increased on EBV-infected lymphoma cells. Regarding the underlying molecular mechanisms, higher PD-L1 and/or PD-L2 expression levels were associated with a gain of chromosome 9p24 on neoplastic cHL cells $[263,264]$, since PD-L1 is induced by the EBV-encoded LMP1 through the NF-kB pathway in NK/T cell lymphoma [265] and in DLBCLs by the EBNA2 gene product. The latter was confirmed by in vitro studies of EBNA2 overexpression leading to an upregulation of PD-L1 due to downregulation of the PD-L1 targeting human endogenous miR-34a [266]. However, it is noteworthy that the EBV miR-BHRF1-2-5p has a counter-regulatory role by fine-tuning the LMP1-mediated upregulation of PD-L1 and PDL2 [267]. Furthermore, the expression levels of TIM-3, LAG-3 and VISTA were upregulated in EBV-specific T cells, which is accompanied by the impairment of LMP1/2-specific T-cell function, and were directly associated with a high viral load [268,269]. However, with the exception of the PD1/PD-L1 system, the expression levels and the role of immune checkpoints in EBV-associated malignancies have not yet been systematically evaluated.

\subsubsection{Altered Regulation of Inflammatory Signal Transduction Pathways} and Soluble Factors

Inflammatory signaling processes play a key role in some EBV-associated malignancies, e.g., NPC tumorigenesis. These include the activation of the NF-kB signaling pathways, 
which affect growth properties but also immune evasion by modulating the composition of the TME. During EBV infection, various pattern recognition receptor signaling pathways are activated and targeted by latent and/or lytic EBV proteins or by EBV-specific miRs to minimize their anti-viral activity as summarized in Table 6. For example, BGLF5, which is expressed during the productive phase of infection, leads to the RNA degradation of immunologically relevant proteins, such as the Toll-like receptor (TLR) 2 and TLR-9 [245]. The TLR signaling pathways can activate NF-kB, which is controlled by various posttranslational modifications [270]. These modifications could be affected by EBV-encoded proteins, such as BGLF4, which suppresses NF-kB activity and by BPLF1, which reverses the ubiquitination of TLR signaling intermediates [245]. Furthermore, LMP1 downregulates the expression of the tumor necrosis factor (TNF) $\alpha$, [134,271]. Another pro-inflammatory cytokine signaling inhibited by the miR-BHRF1-2-5p targets the IL-1 receptor 1 thereby interfering with the pro-inflammatory signaling required for early activation of components of the innate immune system [272]. While IL- 6 and IL-12 are regulated by 5 EBV-specific miRs in early infection leading to a suppressed Th1 differentiation [273], the chemokine CXCL11 is targeted by BHFR1 miRs thereby affecting the recruitment of CD8 ${ }^{+} \mathrm{T}$ cells [274]. Furthermore, the interferon (IFN) signaling pathway is altered by EBV infection. A number of EBV-encoded genes can affect different components of the IFN signal transduction pathways, such as STAT1, IFN receptors, IFN-stimulated genes (ISGs) and IFN-regulatory factors (IRFs), as summarized in Table 6.

Table 6. Immune escape mechanisms and EBV-encoded gene products involved.

\begin{tabular}{|c|c|c|c|}
\hline Component & Gene Product & Mechanism & Reference \\
\hline \multirow{6}{*}{ HLA class I } & BGLF5 & $\begin{array}{c}\text { degradation of HLA } \\
\text { class I }\end{array}$ & {$[235,245]$} \\
\hline & BNLF2a & $\begin{array}{l}\text { inhibition of peptide } \\
\text { transport by blocking }\end{array}$ & {$[233,240,241]$} \\
\hline & BILF1 & $\begin{array}{c}\text { impaired HLA class I } \\
\text { export } \\
\text { increased turnover of } \\
\text { HLA class I surface } \\
\text { molecules }\end{array}$ & {$[234,237,238,275]$} \\
\hline & BCRF1 (vIL-10) & $\begin{array}{l}\text { inhibition of HLA } \\
\text { class I }\end{array}$ & [251] \\
\hline & EBNA1 & $\begin{array}{l}\text { disruption of peptide } \\
\text { generation and } \\
\text { transport }\end{array}$ & [239] \\
\hline & EBNA2 & $\begin{array}{l}\text { inhibition of peptide } \\
\text { generation and } \\
\text { presentation }\end{array}$ & [243] \\
\hline \multirow{4}{*}{ HLA class II } & gp42 (BZLF2) & $\begin{array}{l}\text { block of TCR/HLA } \\
\text { class II interaction }\end{array}$ & {$[246,247]$} \\
\hline & BGLF5 & $\begin{array}{c}\text { degradation of HLA } \\
\text { class II }\end{array}$ & [245] \\
\hline & Zta & $\begin{array}{l}\text { inhibition of CIITA } \\
\text { promoter activity, } \\
\text { posttranscriptional } \\
\text { regulation by } \\
\text { impairing function of } \\
\text { the invariant chain }\end{array}$ & [248] \\
\hline & BCRF1 (vIL-10) & $\begin{array}{l}\text { inhibition of HLA } \\
\text { class II expression }\end{array}$ & [276] \\
\hline
\end{tabular}


Table 6. Cont.

\begin{tabular}{|c|c|c|c|}
\hline Component & Gene Product & Mechanism & Reference \\
\hline Checkpoints & LMP1 & $\begin{array}{l}\text { induction of soluble } \\
\text { PD-L1 }\end{array}$ & [277] \\
\hline \multirow{7}{*}{$\begin{array}{l}\text { TLR/NF-kB } \\
\text { pathway }\end{array}$} & BGLF5 & $\begin{array}{l}\text { downregulation of } \\
\text { TLR-2 and -9 }\end{array}$ & [245] \\
\hline & BZLF1 & inhibition of NF-kB & [278] \\
\hline & BGLF4 & $\begin{array}{l}\text { suppression of NF-kB } \\
\text { activity }\end{array}$ & [279] \\
\hline & BPLF1 & $\begin{array}{l}\text { inhibition of NF-kB } \\
\text { activation by } \\
\text { reversion of } \\
\text { ubiquitination of TLR } \\
\text { signaling }\end{array}$ & {$[280,281]$} \\
\hline & EBNA1 & inhibition of NF-kB & [282] \\
\hline & LMP1 & reduction of TLR-9 & [283] \\
\hline & LMP2 & inhibition of NF-kB & [284] \\
\hline \multirow{9}{*}{$\begin{array}{l}\text { IRFs / IFN type I } \\
\text { signaling }\end{array}$} & BZLF1 & $\begin{array}{l}\text { inhibition of IRF7 } \\
\text { transcriptional } \\
\text { activity; reduction of } \\
\text { IFN-Y receptor }\end{array}$ & {$[271,285]$} \\
\hline & BILF4 & inhibition of IRF7 & [286] \\
\hline & BGLF4 & inhibition of IRF3 & [287] \\
\hline & BRLF1 & $\begin{array}{l}\text { reduction of IRF3 and } \\
\text { IRF7 expression }\end{array}$ & [288] \\
\hline & EBNA1 & $\begin{array}{l}\text { modulation of STAT1 } \\
\text { signaling }\end{array}$ & [289] \\
\hline & EBNA-2 & inhibition of ISGs & {$[290,291]$} \\
\hline & LMP-1 & regulation of STAT1 & [292] \\
\hline & LMP-2a & $\begin{array}{l}\text { inhibition of } \\
\text { JAK/STAT signaling, } \\
\text { acceleration of IFN } \\
\text { receptor turnover }\end{array}$ & [293] \\
\hline & LMP-2b & $\begin{array}{l}\text { acceleration of IFN } \\
\text { receptor degradation }\end{array}$ & [293] \\
\hline
\end{tabular}

\subsubsection{Downregulated Molecules Modulating Innate Immune Cells}

Innate immune cells play an important role in the host response against viral infections including EBV [294]. Immune responses directed against virus-associated malignancies are also modulated by downregulation of ligands for activation receptors of immune effector cells, in particular the NKG2D ligands including MICA/B as well as ULBP1-6. The expression of several ligands of the activation receptor NKG2D, which is induced upon, e.g., cellular stress, viral infections and inflammation, is downregulated upon EBV infection, such as MICA and MICB. This is controlled by EBV-miR-BART7 and EBV-miR-BART2$5 p[135,295]$ negatively interfering with NK cell responses. The enhanced recruitment and activation of Tregs, the subsequent anergy of $\mathrm{CD} 8^{+}$cytotoxic $\mathrm{T}$ cells, the crosstalk with tumor-growth-promoting M2 macrophages and the overexpression of the immunesuppressive enzyme indoleamine 2,3-deoxygenase (IDO) are also involved in immune evasion [296-298]. 


\subsection{Clinical Relevance of EBV in Malignancies}

Based on the diverse immune escape strategies described, a link of EBV infection with disease progression and response to therapy including immunotherapies is obvious. EBV-positive NPCs have been associated with significantly worse survival compared to EBV-negative patients [299,300], which is due to the induction of an immune-suppressive TME. This is in line with many other different EBV-induced tumor types, in which the immune-suppressive TME has been correlated with the patient outcome. In contrast, higher numbers of TILs have been shown to be associated with an improved survival of EBV-associated NPC, GC and ICC patients $[23,114,150]$. Thus, there exists growing evidence that the prognosis of patients with EBV-associated malignancies is influenced by different immune cell populations. While increased numbers of effector $\mathrm{T}$ cells, $\mathrm{B}$ cells and NK cells have been related to better survival [119], higher numbers of Tregs, inhibitory DC subsets and M2-polarized TAMs known to support an immune-suppressive TME are associated with shorter disease-free survival $[128,149,301]$. Of note, BLs with a proinflammatory TME characterized by higher levels of M1-polarized TAMs and associated granulomatous reaction have a favorable prognosis and an occasionally spontaneous regression [302]. However, not only the frequencies of the different immune cell subsets but also their functional status are of clinical relevance. Exhausted T-cell subsets and increased numbers of highly dominant T-cell clones with a consecutive limited TCR repertoire are contributing to an immune cell dysregulation supporting the immune surveillance and have been shown to be associated with worse patient survival [152]. Since the expression of immune checkpoints is one key mechanism of tumors to escape the host immune system, it is not surprising that the expression of PD-L1 is associated with the patient prognosis. However, its prognostic significance remains controversial, and the impact on the prognosis is dependent on the tumor type $[103,114,127,178]$. In DLBCL and cHL, EBV-positive tumors with high PD-L1 expression showed a significantly shortened overall survival compared to other subtypes [303]. Furthermore, a high PD-L1 expression correlated with high EBV copy numbers suggesting that the EBV load contributes to the expression levels of checkpoint molecules [304]. Low-dose anti-PD1 antibodies were highly efficacious and safe in patients with relapsed/refractory cHL and improved their survival [305]. In EBV-positive NPC and GC, higher PD-L1 expression was associated with improved survival [300,306]. An enhanced efficacy of PD-L1/PD-1 blockade was shown in patients, which was accompanied by numbers of M1 TAMs [307] further suggesting EBV-positive NPC and EBV-positive GC as ideal candidates for PD-1-directed therapies [308]. Furthermore, the antigen presentation via HLA class I molecules is deregulated in many EBV-positive malignancies thereby affecting anti-tumoral immune responses, which has been also associated with worse patient survival [150].

Taken together, a strong impact of intrinsic and extrinsic immune escape mechanisms, in particular, on the local immune cell composition has been demonstrated. Therefore, different immune therapeutic approaches have been investigated in preclinical and clinical studies. Next to the immune checkpoint blockade, the spectrum of therapeutic strategies encompasses anti-viral drugs, small molecules, cytokines and cellular vaccination or T-cell therapy. Combination therapies of chemotherapy and anti-viral drugs, such as ganciclovir, resulted in a strong synergistic effect with higher cytotoxicity compared with chemotherapy alone and subsequently led to disease stabilization [309].

It has been demonstrated that EBNA-1 inhibitors are potent and selective inhibitors of cell growth in tissue culture and animal models of EBV-positive GC suggesting that pharmacological targeting of this latent EBV gene product may be an effective strategy to treat patients with EBV-positive GC [310]. Furthermore, a combination of betulinic acid and Chidamide (CDM, CS055), a novel histone deacetylase inhibitor (HDACi), could significantly inhibit EBV replication with ROS over-generation and subsequent DNA damage and apoptosis [311]. First studies with an LMP-2 DC vaccine in patients with NPC showed specific CD8 ${ }^{+}$T-cell responses directed against LMP-2, which plays a critical role in controlling and preventing the recurrence and metastasis formation of NPC [312]. Currently, 
there are multiple trials testing the use of both donor-derived and third-party EBV- specific $\mathrm{T}$ cells in the setting of treatment-refractory EBV-positive malignancies. First trials with chimeric antigen receptor (CAR) $T$ cells against latent EBV antigens but also against early lytic viral gene products have been carried out. These CARs appear to be protective for the control of EBV infection and EBV-mediated oncogenesis thereby providing a novel promising therapeutic strategy against EBV-associated malignancies [53,313,314].

\title{
5. Conclusions
}

The Epstein-Barr virus was first described in 1964, in African endemic BL samples [1]. However, more than 50 years later, the detailed mechanisms of EBV in disease initiation and progression are still not completely understood. However, there exists strong evidence that EBV latent gene and miR expression simultaneously target different intracellular pathways in EBV-infected cells and thereby modulate the TME to the gene's benefits. After an unusual immune-cell-rich TME was initially observed, different immune cell subpopulations and their function were examined, and a predominantly immunosuppressive TME could be proven in the following years. Interestingly, a highly variable but distinct composition of the TME with increased numbers of effector T cells and Tregs was observed [23,131,148]. This is also supported by soluble factors such as IL-10 which is upregulated in most EBV-positive tumors thereby inducing Tregs, which results in suppression of effector T-cell function [185,188,190-192]. In addition, the EBV latency gene product LMP-1 suppresses the function of effector T cells and can be presented by tumor cells, extracellular vesicles or antigen-presenting DCs. Other strategies of the tumor cells to escape the immune surveillance are the downregulation of MHC class I molecules or upregulation of non-classical HLA-G. Furthermore, higher expression levels of the immune checkpoint molecules PD-L1 have been shown in almost all EBV-positive tumors and have been shown to be regulated by EBV. It is obvious that EBV-positive tumors are able to develop a multitude of mechanisms to escape immune surveillance. Thus, one single therapeutic strategy might be often not sufficient for disease control. Increased insights into the TME and tumor-intrinsic immune escape strategies will help to design and improve (immuno) therapeutic strategies. Currently, immune checkpoint blockade, such as PD-1/PD-L1 antibodies, small molecules targeting EBV latency gene product, cellular vaccination and CAR T-cell therapy against EBV antigens seem to offer promising therapy options [53,308,310-312].

Author Contributions: All authors contributed to the contents of this review. B.S. designed the review; M.B., S.J.-B., O.M., C.W. and B.S. wrote the article; M.B. provided the tables and figures. All authors have read and agreed to the published version of the manuscript.

Funding: This review was supported by grants from the German-Israeli Foundation (two GIF grants I-37-414.11-2016) (O.M., B.S.), the Jackstädt Foundation (S.J.-B.) and the BMBF (Epi-Lymph) (C.W., B.S.). In addition, we acknowledge the financial support of the Open Access Publication Fund of the Martin Luther University Halle-Wittenberg.

Acknowledgments: We would like to thank Nicole Ott for excellent secretarial help.

Conflicts of Interest: All authors declare that there is no conflict of interest.

\author{
Abbreviations \\ APC antigen-presenting cell \\ BART BamHI fragment A rightward transcript \\ BHRF1 BamHI fragment $H$ rightward transcript 1 \\ BL Burkitt lymphoma \\ CAF cancer-associated fibroblast \\ cHL classical Hodgkin lymphoma \\ CAR chimeric antigen receptor
}




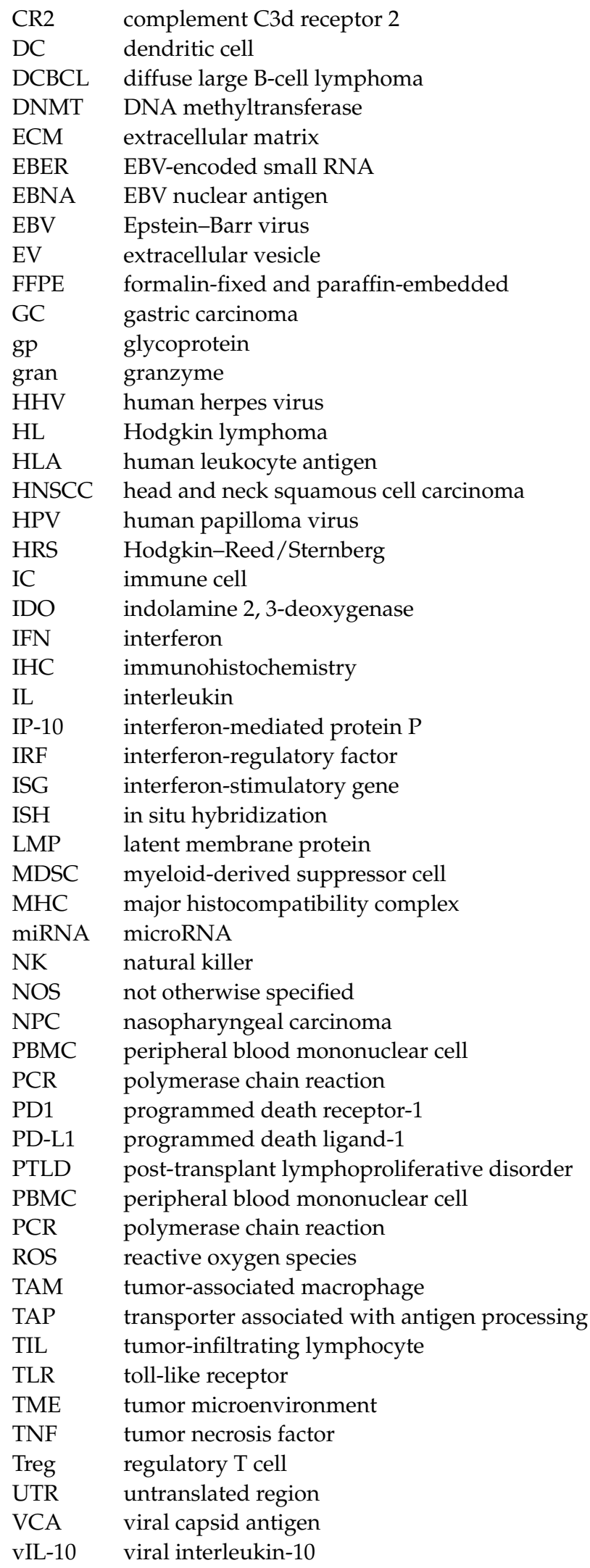




\section{References}

1. Epstein, M.A.; Achong, B.G.; Barr, Y.M. Virus particles in cultured lymphoblasts from burkitt's lymphoma. Lancet 1964, 283, 702-703. [CrossRef]

2. Shannon-Lowe, C.; Rickinson, A. The Global Landscape of EBV-Associated Tumors. Front. Oncol. 2019, 9, 713. [CrossRef] [PubMed]

3. Dunmire, S.K.; Verghese, P.S.; Balfour, H.H. Primary Epstein-Barr Virus Infection. J. Clin. Virol. Off. Publ. Pan. Am. Soc. Clin. Virol. 2018, 102, 84-92. [CrossRef] [PubMed]

4. Smatti, M.K.; Al-Sadeq, D.W.; Ali, N.H.; Pintus, G.; Abou-Saleh, H.; Nasrallah, G.K. Epstein-Barr Virus Epidemiology, Serology, and Genetic Variability of LMP-1 Oncogene Among Healthy Population: An Update. Front. Oncol. 2018, 8, 211. [CrossRef]

5. Machon, C.; Fabrega-Ferrer, M.; Zhou, D.; Cuervo, A.; Carrascosa, J.L.; Stuart, D.I.; Coll, M. Atomic Structure of the Epstein-Barr Virus Portal. Nat. Commun. 2019, 10, 3891. [CrossRef]

6. Liebowitz, D.; Wang, D.; Kieff, E. Orientation and Patching of the Latent Infection Membrane Protein Encoded by Epstein-Barr Virus. J. Virol. 1986, 58, 233-237. [CrossRef]

7. Rivailler, P.; Cho, Y.G.; Wang, F. Complete Genomic Sequence of an Epstein-Barr Virus-Related Herpesvirus Naturally Infecting a New World Primate: A Defining Point in the Evolution of Oncogenic Lymphocryptoviruses. J. Virol. 2002, 76, 12055-12068 [CrossRef]

8. Sample, J.; Young, L.; Martin, B.; Chatman, T.; Kieff, E.; Rickinson, A.; Kieff, E. Epstein-Barr Virus Types 1 and 2 Differ in Their EBNA-3A, EBNA-3B, and EBNA-3C Genes. J. Virol. 1990, 64, 4084-4092. [CrossRef]

9. Dolan, A.; Addison, C.; Gatherer, D.; Davison, A.J.; McGeoch, D.J. The Genome of Epstein-Barr Virus Type 2 Strain AG876. Virology 2006, 350, 164-170. [CrossRef]

10. Zimber, U.; Adldinger, H.K.; Lenoir, G.M.; Vuillaume, M.; Knebel-Doeberitz, M.V.; Laux, G.; Desgranges, C.; Wittmann, P.; Freese, U.K.; Schneider, U. Geographical Prevalence of Two Types of Epstein-Barr Virus. Virology 1986, 154, 56-66. [CrossRef]

11. Zanella, L.; Reyes, M.E.; Riquelme, I.; Abanto, M.; Leon, D.; Viscarra, T.; Ili, C.; Brebi, P. Genetic Patterns Found in the Nuclear Localization Signals (NLSs) Associated with EBV-1 and EBV-2 Provide New Insights into Their Contribution to Different Cell-Type Specificities. Cancers 2021, 13, 2569. [CrossRef]

12. Chetham, M.M.; Roberts, K.B. Infectious Mononucleosis in Adolescents. Pediatr. Ann. 1991, 20, 206-213. [CrossRef]

13. Dugan, J.P.; Coleman, C.B.; Haverkos, B. Opportunities to Target the Life Cycle of Epstein-Barr Virus (EBV) in EBV-Associated Lymphoproliferative Disorders. Front. Oncol. 2019, 9, 127. [CrossRef]

14. International Agency for Research on Cancer. IARC Working Group on the Evaluation of Carcinogenic Risk to Humans; Biological Agents: Lyon, France, 2012.

15. Chijioke, O.; Müller, A.; Feederle, R.; Barros, M.H.M.; Krieg, C.; Emmel, V.; Marcenaro, E.; Leung, C.S.; Antsiferova, O.; Landtwing, V.; et al. Human Natural Killer Cells Prevent Infectious Mononucleosis Features by Targeting Lytic Epstein-Barr Virus Infection. Cell Rep. 2013, 5, 1489-1498. [CrossRef]

16. Damania, B.; Munz, C. Immunodeficiencies That Predispose to Pathologies by Human Oncogenic Gamma-Herpesviruses. FEMS Microbiol. Rev. 2019, 43, 181-192. [CrossRef]

17. Alsafadi, N.; Alqarni, M.S.; Attar, M.; Mgarry, R.; Bokhari, A. Nasopharyngeal Cancer: Prevalence, Outcome, and Impact on Health-Related Quality of Life at Princess Norah Oncology Center, Jeddah, Saudi Arabia. Cureus 2020, 12, e8199. [CrossRef]

18. Tavakoli, A.; Monavari, S.H.; Solaymani Mohammadi, F.; Kiani, S.J.; Armat, S.; Farahmand, M. Association between Epstein-Barr Virus Infection and Gastric Cancer: A Systematic Review and Meta-Analysis. BMC Cancer 2020, 20, 493. [CrossRef]

19. Huang, X.; Nolte, I.; Gao, Z.; Vos, H.; Hepkema, B.; Poppema, S.; van den Berg, A.; Diepstra, A. Epidemiology of Classical Hodgkin Lymphoma and Its Association with Epstein Barr Virus in Northern China. PLoS ONE 2011, 6, e21152. [CrossRef]

20. Ogwang, M.D.; Bhatia, K.; Biggar, R.J.; Mbulaiteye, S.M. Incidence and Geographic Distribution of Endemic Burkitt Lymphoma in Northern Uganda Revisited. Int. J. Cancer 2008, 123, 2658-2663. [CrossRef]

21. Jiang, X.N.; Zhang, Y.; Xue, T.; Chen, J.Y.; Chan, A.C.L.; Cheuk, W.; Chan, J.K.C.; Li, X.Q. New Clinicopathologic Scenarios of EBV+ Inflammatory Follicular Dendritic Cell Sarcoma: Report of 9 Extrahepatosplenic Cases. Am. J. Surg. Pathol. 2021, 45, 765-772. [CrossRef]

22. Chang, E.T.; Ye, W.; Zeng, Y.X.; Adami, H.O. The Evolving Epidemiology of Nasopharyngeal Carcinoma. Cancer Epidemiol. Biomark. Prev. 2021, 30, 1035-1047. [CrossRef]

23. Huang, Y.-H.; Zhang, C.Z.; Huang, Q.-S.; Yeong, J.; Wang, F.; Yang, X.; He, Y.-F.; Zhang, X.-L.; Zhang, H.; Chen, S.-L.; et al. Clinicopathologic Features, Tumor Immune Microenvironment and Genomic Landscape of Epstein-Barr Virus-Associated Intrahepatic Cholangiocarcinoma. J. Hepatol. 2021, 74, 838-849. [CrossRef]

24. Yin, L.; Xu-Monette, Z.Y.; Brock, J.; Li, Y.; Young, K.H. Different Prevalence and Clinical Outcome of Epstein-Barr Virus Positive Diffuse Large B-Cell Lymphoma between North American and Non-Western Populations. Ann. Transl. Med. $2018,6,236$. [CrossRef]

25. Beltran, B.E.; Castro, D.; Paredes, S.; Miranda, R.N.; Castillo, J.J. EBV-Positive Diffuse Large B-Cell Lymphoma, Not Otherwise Specified: 2020 Update on Diagnosis, Risk-Stratification and Management. Am. J. Hematol. 2020, 95, 435-445. [CrossRef]

26. Chang, E.T.; Adami, H.O. The Enigmatic Epidemiology of Nasopharyngeal Carcinoma. Cancer Epidemiol. Biomark. Prev. 2006, 15, 1765-1777. [CrossRef] 
27. Sun, K.; Jia, K.; Lv, H.; Wang, S.Q.; Wu, Y.; Lei, H.; Chen, X. EBV-Positive Gastric Cancer: Current Knowledge and Future Perspectives. Front. Oncol. 2020, 10, 583463. [CrossRef]

28. Hamashima, C. The Burden of Gastric Cancer. Ann. Transl. Med. 2020, 8, 734. [CrossRef]

29. Gearty, S.V.; Al Jurdi, A.; Pittman, M.E.; Gupta, R. An EBV+ Lymphoepithelioma-like Cholangiocarcinoma in a Young Woman with Chronic Hepatitis, B. BMJ Case Rep. 2019, 12, e229520. [CrossRef]

30. Banales, J.M.; Marin, J.J.G.; Lamarca, A.; Rodrigues, P.M.; Khan, S.A.; Roberts, L.R.; Cardinale, V.; Carpino, G.; Andersen, J.B.; Braconi, C.; et al. Cholangiocarcinoma 2020: The next Horizon in Mechanisms and Management. Nat. Rev. Gastroenterol. Hepatol. 2020, 17, 557-588. [CrossRef]

31. Kimura, H. Clinical and Virologic Characteristics of Chronic Active Epstein-Barr Virus Infection. Blood 2001, 98, 280-286. [CrossRef] [PubMed]

32. Wass, M.; Bauer, M.; Pfannes, R.; Lorenz, K.; Odparlik, A.; Muller, L.P.; Wickenhauser, C. Chronic Active Epstein-Barr Virus Infection of T-Cell Type, Systemic Form in an African Migrant: Case Report and Review of the Literature on Diagnostics Standards and Therapeutic Options. BMC Cancer 2018, 18, 941. [CrossRef] [PubMed]

33. Roberts, T.K.; Chen, X.; Liao, J.J. Diagnostic and Therapeutic Challenges of EBV-Positive Mucocutaneous Ulcer: A Case Report and Systematic Review of the Literature. Exp. Hematol. Oncol. 2015, 5, 13. [CrossRef] [PubMed]

34. Katzenstein, A.L.; Carrington, C.B.; Liebow, A.A. Lymphomatoid Granulomatosis: A Clinicopathologic Study of 152 Cases. Cancer 1979, 43, 360-373. [CrossRef]

35. Song, J.Y.; Pittaluga, S.; Dunleavy, K.; Grant, N.; White, T.; Jiang, L.; Davies-Hill, T.; Raffeld, M.; Wilson, W.H.; Jaffe, E.S. Lymphomatoid Granulomatosis-A Single Institute Experience: Pathologic Findings and Clinical Correlations. Am. J. Surg. Pathol. 2015, 39, 141-156. [CrossRef] [PubMed]

36. Bouchekioua, A.; Scourzic, L.; de Wever, O.; Zhang, Y.; Cervera, P.; Aline-Fardin, A.; Mercher, T.; Gaulard, P.; Nyga, R.; Jeziorowska, D.; et al. JAK3 Deregulation by Activating Mutations Confers Invasive Growth Advantage in Extranodal Nasal-Type Natural Killer Cell Lymphoma. Leukemia 2014, 28, 338-348. [CrossRef]

37. Wang, H.; Li, P.; Zhang, X.; Xia, Z.; Lu, Y.; Huang, H. Histological Vascular Invasion Is a Novel Prognostic Indicator in Extranodal Natural Killer/T-Cell Lymphoma, Nasal Type. Oncol. Lett. 2016, 12, 825-836. [CrossRef]

38. Smith, N.; Tierney, R.; Wei, W.; Vockerodt, M.; Murray, P.G.; Woodman, C.B.; Rowe, M. Induction of Interferon-Stimulated Genes on the IL-4 Response Axis by Epstein-Barr Virus Infected Human b Cells; Relevance to Cellular Transformation. PLoS ONE 2013, 8, e64868. [CrossRef]

39. Ibrahim, H.A.; Naresh, K.N. Posttransplant Lymphoproliferative Disorders. Adv. Hematol. 2012, 2012, 230173. [CrossRef]

40. Smith, A.; Crouch, S.; Lax, S.; Li, J.; Painter, D.; Howell, D.; Patmore, R.; Jack, A.; Roman, E. Lymphoma Incidence, Survival and Prevalence 2004-2014: Sub-Type Analyses from the UK's Haematological Malignancy Research Network. Br. J. Cancer 2015, 112, 1575-1584. [CrossRef]

41. Federico, M.; Rudiger, T.; Bellei, M.; Nathwani, B.N.; Luminari, S.; Coiffier, B.; Harris, N.L.; Jaffe, E.S.; Pileri, S.A.; Savage, K.J.; et al. Clinicopathologic Characteristics of Angioimmunoblastic T-Cell Lymphoma: Analysis of the International Peripheral T-Cell Lymphoma Project. J. Clin. Oncol. 2013, 31, 240. [CrossRef]

42. Eladl, A.E.; Shimada, K.; Suzuki, Y.; Takahara, T.; Kato, S.; Kohno, K.; Elsayed, A.A.; Wu, C.C.; Tokunaga, T.; Kinoshita, T.; et al. EBV Status Has Prognostic Implication among Young Patients with Angioimmunoblastic T-Cell Lymphoma. Cancer Med. 2020, 9 , 678-688. [CrossRef]

43. Mbulaiteye, S.M.; Anderson, W.F.; Bhatia, K.; Rosenberg, P.S.; Linet, M.S.; Devesa, S.S. Trimodal Age-Specific Incidence Patterns for Burkitt Lymphoma in the United States, 1973-2005. Int. J. Cancer 2010, 126, 1732-1739. [CrossRef]

44. Horvat, M.; Zadnik, V.; Juznic Setina, T.; Boltezar, L.; Pahole Golicnik, J.; Novakovic, S.; Jezersek Novakovic, B. Diffuse Large B-Cell Lymphoma: 10 Years' Real-World Clinical Experience with Rituximab plus Cyclophosphamide, Doxorubicin, Vincristine and Prednisolone. Oncol. Lett. 2018, 15, 3602-3609. [CrossRef]

45. Ramdial, P.K.; Sing, Y.; Deonarain, J.; Hadley, G.P.; Singh, B. Dermal Epstein Barr Virus-Associated Leiomyosarcoma: Tocsin of Acquired Immunodeficiency Syndrome in Two Children. Am. J. Dermatopathol. 2011, 33, 392-396. [CrossRef]

46. Agaimy, A.; Wunsch, P.H. Follicular Dendritic Cell Tumor of the Gastrointestinal Tract: Report of a Rare Neoplasm and Literature Review. Pathol. Res. Pr. 2006, 202, 541-548. [CrossRef]

47. Hutt-Fletcher, L.M. The Long and Complicated Relationship between Epstein-Barr Virus and Epithelial Cells. J. Virol. 2017, 91, e01677-16. [CrossRef]

48. Speck, P.; Haan, K.M.; Longnecker, R. Epstein-Barr Virus Entry into Cells. Virology 2000, 277, 1-5. [CrossRef]

49. Thorley-Lawson, D.A. EBV Persistence-Introducing the Virus. Curr. Top. Microbiol. Immunol. 2015, 390, 151-209. [CrossRef]

50. Tierney, R.J.; Shannon-Lowe, C.D.; Fitzsimmons, L.; Bell, A.I.; Rowe, M. Unexpected Patterns of Epstein-Barr Virus Transcription Revealed by a High Throughput PCR Array for Absolute Quantification of Viral MRNA. Virology 2015, 474, 117-130. [CrossRef]

51. Kang, M.-S.; Kieff, E. Epstein-Barr Virus Latent Genes. Exp. Mol. Med. 2015, 47, e131. [CrossRef]

52. Cao, Y.; Xie, L.; Shi, F.; Tang, M.; Li, Y.; Hu, J.; Zhao, L.; Zhao, L.; Yu, X.; Luo, X.; et al. Targeting the Signaling in Epstein-Barr Virus-Associated Diseases: Mechanism, Regulation, and Clinical Study. Signal. Transduct. Target Ther. 2021, 6, 15. [CrossRef]

53. Münz, C. Immune Escape by Non-Coding RNAs of the Epstein Barr Virus. Front. Microbiol. 2021, 12, 657387. [CrossRef]

54. Taylor, G.S.; Long, H.M.; Brooks, J.M.; Rickinson, A.B.; Hislop, A.D. The Immunology of Epstein-Barr Virus-Induced Disease. Annu. Rev. Immunol. 2015, 33, 787-821. [CrossRef] 
55. Lin, T.-Y.; Chu, Y.-Y.; Yang, Y.-C.; Hsu, S.-W.; Liu, S.-T.; Chang, L.-K. MCAF1 and Rta-Activated BZLF1 Transcription in Epstein-Barr Virus. PLoS ONE 2014, 9, e90698. [CrossRef]

56. Jia, Y.; Wang, Y.; Chao, Y.; Jing, Y.; Sun, Z.; Luo, B. Sequence Analysis of the Epstein-Barr Virus (EBV) BRLF1 Gene in Nasopharyngeal and Gastric Carcinomas. Virol. J. 2010, 7, 341. [CrossRef]

57. Münz, C. Latency and Lytic Replication in Epstein-Barr Virus-Associated Oncogenesis. Nat. Rev. Microbiol. 2019, 17, 691-700. [CrossRef]

58. De Martel, C.; Ferlay, J.; Franceschi, S.; Vignat, J.; Bray, F.; Forman, D.; Plummer, M. Global Burden of Cancers Attributable to Infections in 2008: A Review and Synthetic Analysis. Lancet Oncol. 2012, 13, 607-615. [CrossRef]

59. Khan, G.; Hashim, M.J. Global Burden of Deaths from Epstein-Barr Virus Attributable Malignancies 1990-2010. Infect. Agent. Cancer 2014, 9, 38. [CrossRef]

60. Stuhlmann-Laeisz, C.; Oschlies, I.; Klapper, W. Detection of EBV in Reactive and Neoplastic Lymphoproliferations in AdultsWhen and How? J. Hematop. 2014, 7, 165-170. [CrossRef]

61. Iizasa, H.; Kim, H.; Kartika, A.V.; Kanehiro, Y.; Yoshiyama, H. Role of Viral and Host MicroRNAs in Immune Regulation of Epstein-Barr Virus-Associated Diseases. Front. Immunol. 2020, 11, 367. [CrossRef]

62. Seto, E.; Moosmann, A.; Gromminger, S.; Walz, N.; Grundhoff, A.; Hammerschmidt, W. Micro RNAs of Epstein-Barr Virus Promote Cell Cycle Progression and Prevent Apoptosis of Primary Human B Cells. PLoS Pathog. 2010, 6, e1001063. [CrossRef] [PubMed]

63. McKenzie, J.; El-Guindy, A. Epstein-Barr Virus Lytic Cycle Reactivation. Curr. Top. Microbiol. Immunol. 2015, 391, $237-261$. [CrossRef] [PubMed]

64. Grimson, A.; Farh, K.K.; Johnston, W.K.; Garrett-Engele, P.; Lim, L.P.; Bartel, D.P. MicroRNA Targeting Specificity in Mammals: Determinants beyond Seed Pairing. Mol. Cell. 2007, 27, 91-105. [CrossRef] [PubMed]

65. Jasinski-Bergner, S.; Kielstein, H. Adipokines Regulate the Expression of Tumor-Relevant MicroRNAs. Obes. Facts 2019, 12, 211-225. [CrossRef]

66. Liu, J.; Valencia-Sanchez, M.A.; Hannon, G.J.; Parker, R. MicroRNA-Dependent Localization of Targeted MRNAs to Mammalian P-Bodies. Nat. Cell Biol. 2005, 7, 719-723. [CrossRef]

67. Fani, M.; Zandi, M.; Rezayi, M.; Khodadad, N.; Langari, H.; Amiri, I. The Role of MicroRNAs in the Viral Infections. Curr. Pharm. Des. 2018, 24, 4659-4667. [CrossRef]

68. Feederle, R.; Haar, J.; Bernhardt, K.; Linnstaedt, S.D.; Bannert, H.; Lips, H.; Cullen, B.R.; Delecluse, H.J. The Members of an Epstein-Barr Virus MicroRNA Cluster Cooperate to Transform B Lymphocytes. J. Virol. 2011, 85, 9801-9810. [CrossRef]

69. Niller, H.H.; Bauer, G. Epstein-Barr Virus: Clinical Diagnostics. Methods Mol. Biol. 2017, 1532, 33-55. [CrossRef]

70. Fan, H.; Gulley, M.L. Molecular Methods for Detecting Epstein-Barr Virus (Part I): In Situ Hybridization to Epstein-Barr VirusEncoded RNA (EBER) Transcripts. In Molecular Pathology Protocols; Humana Press: Totowa, NJ, USA, 2000; Volume 49, pp. 301-311. ISBN 978-1-59259-081-0.

71. Wu, T.C.; Mann, R.B.; Epstein, J.I.; MacMahon, E.; Lee, W.A.; Charache, P.; Hayward, S.D.; Kurman, R.J.; Hayward, G.S.; Ambinder, R.F. Abundant Expression of EBER1 Small Nuclear RNA in Nasopharyngeal Carcinoma. A Morphologically Distinctive Target for Detection of Epstein-Barr Virus in Formalin-Fixed Paraffin-Embedded Carcinoma Specimens. Am. J. Pathol. 1991, 138, 1461-1469.

72. Gulley, M.L. Molecular Diagnosis of Epstein-Barr Virus-Related Diseases. J. Mol. Diagn. 2001, 3, 1-10. [CrossRef]

73. Gulley, M.L.; Glaser, S.L.; Craig, F.E.; Borowitz, M.; Mann, R.B.; Shema, S.J.; Ambinder, R.F. Guidelines for Interpreting EBER In Situ Hybridization and LMP1 Immunohistochemical Tests for Detecting Epstein-Barr Virus in Hodgkin Lymphoma. Am. J. Clin. Pathol. 2002, 117, 259-267. [CrossRef]

74. Lo, Y.M.; Chan, L.Y.; Lo, K.W.; Leung, S.F.; Zhang, J.; Chan, A.T.; Lee, J.C.; Hjelm, N.M.; Johnson, P.J.; Huang, D.P. Quantitative Analysis of Cell-Free Epstein-Barr Virus DNA in Plasma of Patients with Nasopharyngeal Carcinoma. Cancer Res. 1999, 59, 1188-1191.

75. Buelow, D.; Sun, Y.; Tang, L.; Gu, Z.; Pounds, S.; Hayden, R. Comparative Evaluation of Four Real-Time PCR Methods for the Quantitative Detection of Epstein-Barr Virus from Whole Blood Specimens. J. Mol. Diagn. 2016, 18, 527-534. [CrossRef]

76. Kanakry, J.A.; Hegde, A.M.; Durand, C.M.; Massie, A.B.; Greer, A.E.; Ambinder, R.F.; Valsamakis, A. The Clinical Significance of EBV DNA in the Plasma and Peripheral Blood Mononuclear Cells of Patients with or without EBV Diseases. Blood 2016, 127, 2007-2017. [CrossRef]

77. Krieger, N.; Martinez, O.; Krams, S.; Cox, K.; So, S.; Esquivel, C. Significance of Detecting Epstein-Barr-Specificsequences in the Peripheral Blood of Asymptomatic Pediatric Liver Transplant Recipients. Liver Transpl. 2000, 6, 62-66. [CrossRef]

78. Hassan, R.; White, L.; Stefanoff, C.; de Oliveira, D.; Felisbino, F.E.; Klumb, C.; Bacchi, C.E.; Seuánez, H.N.; Zalcberg, I.R. EpsteinBarr virus (EBV) detection and typing by PCR: A contribution to diagnostic screening of EBV-positive Burkitt's lymphoma. Diagn. Pathol. 2006, 1, 17. [CrossRef]

79. AbuSalah, M.A.H.; Gan, S.H.; Al-Hatamleh, M.A.I.; Irekeola, A.A.; Shueb, R.H.; Yean Yean, C. Recent Advances in Diagnostic Approaches for Epstein-Barr Virus. Pathogens 2020, 9, 226. [CrossRef]

80. Tierney, R.J.; Steven, N.; Young, L.S.; Rickinson, A.B. Epstein-Barr Virus Latency in Blood Mononuclear Cells: Analysis of Viral Gene Transcription during Primary Infection and in the Carrier State. J. Virol. 1994, 68, 7374-7385. [CrossRef]

81. Decker, L.L.; Klaman, L.D.; Thorley-Lawson, D.A. Detection of the Latent Form of Epstein-Barr Virus DNA in the Peripheral Blood of Healthy Individuals. J. Virol. 1996, 70, 3286-3289. [CrossRef] 
82. Stevens, S.J.C.; Vervoort, M.B.H.J.; van den Brule, A.J.C.; Meenhorst, P.L.; Meijer, C.J.L.M.; Middeldorp, J.M. Monitoring of Epstein-Barr Virus DNA Load in Peripheral Blood by Quantitative Competitive PCR. J. Clin. Microbiol. 1999, 37, $2852-2857$. [CrossRef]

83. Pallesen, G.; Hamilton-Dutoit, S.J.; Rowe, M.; Young, L.S. Expression of Epstein-Barr Virus Latent Gene Products in Tumour Cells of Hodgkin's Disease. Lancet 1991, 337, 320-322. [CrossRef]

84. De Paschale, M. Serological Diagnosis of Epstein-Barr Virus Infection: Problems and Solutions. World J. Virol. 2012, 1, 31. [CrossRef]

85. Binnicker, M.J.; Jespersen, D.J.; Harring, J.A.; Rollins, L.O.; Beito, E.M. Evaluation of a Multiplex Flow Immunoassay for Detection of Epstein-Barr Virus-Specific Antibodies. Clin. Vaccine Immunol. 2008, 15, 1410-1413. [CrossRef]

86. Enblad, G.; Sandvej, K.; Lennette, E.; Sundström, C.; Klein, G.; Glimelius, B.; Pallesen, G. Lack of Correlation between EBV Serology and Presence of EBV in the Hodgkin and Reed-Sternberg Cells of Patients with Hodgkin's Disease. Int. J. Cancer 1997, 72, 394-397. [CrossRef]

87. Meckes, D.G.; Raab-Traub, N. Microvesicles and Viral Infection. J. Virol. 2011, 85, 12844-12854. [CrossRef]

88. Van Niel, G.; D'Angelo, G.; Raposo, G. Shedding Light on the Cell Biology of Extracellular Vesicles. Nat. Rev. Mol. Cell Biol. 2018, 19, 213-228. [CrossRef] [PubMed]

89. Ko, Y.H. EBV and Human Cancer. Exp. Mol. Med. 2015, 47, e130. [CrossRef]

90. Shao, H.; Chung, J.; Issadore, D. Diagnostic Technologies for Circulating Tumour Cells and Exosomes. Biosci. Rep. 2015, 36, e00292. [CrossRef]

91. Urbanelli, L.; Buratta, S.; Tancini, B.; Sagini, K.; Delo, F.; Porcellati, S.; Emiliani, C. The Role of Extracellular Vesicles in Viral Infection and Transmission. Vaccines 2019, 7, 102. [CrossRef] [PubMed]

92. Houali, K.; Wang, X.; Shimizu, Y.; Djennaoui, D.; Nicholls, J.; Fiorini, S.; Bouguermouh, A.; Ooka, T. A New Diagnostic Marker for Secreted Epstein-Barr Virus Encoded LMP1 and BARF1 Oncoproteins in the Serum and Saliva of Patients with Nasopharyngeal Carcinoma. Clin. Cancer Res. 2007, 13, 4993-5000. [CrossRef] [PubMed]

93. Mao, Y.; Zhang, D.W.; Zhu, H.; Lin, H.; Xiong, L.; Cao, Q.; Liu, Y.; Li, Q.D.; Xu, J.R.; Xu, L.F.; et al. LMP1 and LMP2A Are Potential Prognostic Markers of Extranodal NK/T-Cell Lymphoma, Nasal Type (ENKTL). Diagn. Pathol. 2012, 7, 178. [CrossRef]

94. Zhao, M.; Nanbo, A.; Sun, L.; Lin, Z. Extracellular Vesicles in Epstein-Barr Virus' Life Cycle and Pathogenesis. Microorganisms 2019, 7, 48. [CrossRef]

95. Teow, S.Y.; Liew, K.; Khoo, A.S.; Peh, S.C. Pathogenic Role of Exosomes in Epstein-Barr Virus (EBV)-Associated Cancers. Int. J. Biol. Sci. 2017, 13, 1276-1286. [CrossRef]

96. Panea, R.I.; Love, C.L.; Shingleton, J.R.; Reddy, A.; Bailey, J.A.; Moormann, A.M.; Otieno, J.A.; Ong'echa, J.M.; Oduor, C.I.; Schroeder, K.M.S.; et al. The Whole-Genome Landscape of Burkitt Lymphoma Subtypes. Blood 2019, 134, 1598-1607. [CrossRef]

97. Deng, W.; Pang, P.S.; Tsang, C.M.; Hau, P.M.; Yip, Y.L.; Cheung, A.L.M.; Tsao, S.W. Epstein-Barr Virus-Encoded Latent Membrane Protein 1 Impairs G2 Checkpoint in Human Nasopharyngeal Epithelial Cells through Defective Chk1 Activation. PLoS ONE 2012, 7, e39095. [CrossRef]

98. Dolcetti, R.; Dal Col, J.; Martorelli, D.; Carbone, A.; Klein, E. Interplay among Viral Antigens, Cellular Pathways and Tumor Microenvironment in the Pathogenesis of EBV-Driven Lymphomas. Semin. Cancer Biol. 2013, 23, 441-456. [CrossRef]

99. Tsimbouri, P.; Drotar, M.E.; Coy, J.L.; Wilson, J.B. Bcl-XL and RAG Genes Are Induced and the Response to IL-2 Enhanced in E $\mu$ EBNA-1 Transgenic Mouse Lymphocytes. Oncogene 2002, 21, 5182-5187. [CrossRef]

100. Gruhne, B.; Sompallae, R.; Marescotti, D.; Kamranvar, S.A.; Gastaldello, S.; Masucci, M.G. The Epstein-Barr Virus Nuclear Antigen-1 Promotes Genomic Instability via Induction of Reactive Oxygen Species. Proc. Natl. Acad. Sci. USA 2009, 106, 2313-2318. [CrossRef]

101. Tsang, C.M.; Lui, V.W.Y.; Bruce, J.P.; Pugh, T.J.; Lo, K.W. Translational Genomics of Nasopharyngeal Cancer. Semin. Cancer Biol. 2020, 61, 84-100. [CrossRef]

102. He, C.; Qiu, M.; Yang, X.; Zhou, D.; Ma, J.; Long, Y.; Ye, Z.; Xu, B.; Zhao, Q.; Jin, Y.; et al. Classification of Gastric Cancer by EBV Status Combined with Molecular Profiling Predicts Patient Prognosis. Clin. Transl. Med. 2020, 10, 353-362. [CrossRef]

103. Cancer Genome Atlas Research Network. Comprehensive Molecular Characterization of Gastric Adenocarcinoma. Nature 2014, 513, 202-209. [CrossRef] [PubMed]

104. Wang, K.; Kan, J.; Yuen, S.T.; Shi, S.T.; Chu, K.M.; Law, S.; Chan, T.L.; Kan, Z.; Chan, A.S.Y.; Tsui, W.Y.; et al. Exome Sequencing Identifies Frequent Mutation of ARID1A in Molecular Subtypes of Gastric Cancer. Nat. Genet. 2011, 43, 1219-1223. [CrossRef] [PubMed]

105. Abate, F.; Ambrosio, M.R.; Mundo, L.; Laginestra, M.A.; Fuligni, F.; Rossi, M.; Zairis, S.; Gazaneo, S.; De Falco, G.; Lazzi, S.; et al. Distinct Viral and Mutational Spectrum of Endemic Burkitt Lymphoma. PLoS Pathog. 2015, 11, e1005158. [CrossRef] [PubMed]

106. Hissong, E.; Ramrattan, G.; Zhang, P.; Zhou, X.K.; Young, G.; Klimstra, D.S.; Shia, J.; Fernandes, H.; Yantiss, R.K. Gastric Carcinomas With Lymphoid Stroma: An Evaluation of the Histopathologic and Molecular Features. Am. J. Surg. Pathol. 2018, 42, 453-462. [CrossRef]

107. Manzano, R.G.; Catalan-Latorre, A.; Brugarolas, A. RB1 and TP53 Co-Mutations Correlate Strongly with Genomic Biomarkers of Response to Immunity Checkpoint Inhibitors in Urothelial Bladder Cancer. BMC Cancer 2021, 21, 432. [CrossRef] 
108. Bernard, E.; Nannya, Y.; Hasserjian, R.P.; Devlin, S.M.; Tuechler, H.; Medina-Martinez, J.S.; Yoshizato, T.; Shiozawa, Y.; Saiki, R.; Malcovati, L.; et al. Implications of TP53 Allelic State for Genome Stability, Clinical Presentation and Outcomes in Myelodysplastic Syndromes. Nat. Med. 2020, 26, 1549-1556. [CrossRef]

109. Courville, E.L.; Yohe, S.; Chou, D.; Nardi, V.; Lazaryan, A.; Thakral, B.; Nelson, A.C.; Ferry, J.A.; Sohani, A.R. EBV-Negative Monomorphic B-Cell Post-Transplant Lymphoproliferative Disorders Are Pathologically Distinct from EBV-Positive Cases and Frequently Contain TP53 Mutations. Mod. Pathol. 2016, 29, 1200-1211. [CrossRef]

110. Ribeiro, J.; Malta, M.; Galaghar, A.; Silva, F.; Afonso, L.P.; Medeiros, R.; Sousa, H. P53 Deregulation in Epstein-Barr VirusAssociated Gastric Cancer. Cancer Lett. 2017, 404, 37-43. [CrossRef]

111. Menter, T.; Juskevicius, D.; Alikian, M.; Steiger, J.; Dirnhofer, S.; Tzankov, A.; Naresh, K.N. Mutational Landscape of B-Cell Post-Transplant Lymphoproliferative Disorders. Br. J. Haematol. 2017, 178, 48-56. [CrossRef]

112. Maggio, E.M.; Stekelenburg, E.; Van den Berg, A.; Poppema, S. TP53 Gene Mutations in Hodgkin Lymphoma Are Infrequent and Not Associated with Absence of Epstein-Barr Virus. Int. J. Cancer 2001, 94, 60-66. [CrossRef]

113. Camargo, M.C.; Kim, K.-M.; Matsuo, K.; Torres, J.; Liao, L.M.; Morgan, D.; Michel, A.; Waterboer, T.; Song, M.; Gulley, M.L.; et al Circulating Antibodies against Epstein-Barr Virus (EBV) and P53 in EBV-Positive and -Negative Gastric Cancer. Cancer Epidemiol. Biomark. Prev. Publ. Am. Assoc. Cancer Res. Cosponsored Am. Soc. Prev. Oncol. 2020, 29, 414-419. [CrossRef]

114. Zhang, L.; MacIsaac, K.D.; Zhou, T.; Huang, P.-Y.; Xin, C.; Dobson, J.R.; Yu, K.; Chiang, D.Y.; Fan, Y.; Pelletier, M.; et al. Genomic Analysis of Nasopharyngeal Carcinoma Reveals TME-Based Subtypes. Mol. Cancer Res. 2017, 15, 1722-1732. [CrossRef]

115. Zheng, H.; Dai, W.; Cheung, A.K.L.; Ko, J.M.Y.; Kan, R.; Wong, B.W.Y.; Leong, M.M.L.; Deng, M.; Kwok, T.C.T.; Chan, J.Y.-W.; et al. Whole-Exome Sequencing Identifies Multiple Loss-of-Function Mutations of NF-KB Pathway Regulators in Nasopharyngeal Carcinoma. Proc. Natl. Acad. Sci. USA 2016, 113, 11283-11288. [CrossRef]

116. Li, Y.Y.; Chung, G.T.Y.; Lui, V.W.Y.; To, K.-F.; Ma, B.B.Y.; Chow, C.; Woo, J.K.S.; Yip, K.Y.; Seo, J.; Hui, E.P. Exome and Genome Sequencing of Nasopharynx Cancer Identifies NF-KB Pathway Activating Mutations. Nat. Commun. 2017, 8, 14121. [CrossRef]

117. Birdwell, C.E.; Queen, K.J.; Kilgore, P.C.; Rollyson, P.; Trutschl, M.; Cvek, U.; Scott, R.S. Genome-Wide DNA Methylation as an Epigenetic Consequence of Epstein-Barr Virus Infection of Immortalized Keratinocytes. J. Virol. 2014, 88, 11442-11458. [CrossRef]

118. Usui, G.; Matsusaka, K.; Mano, Y.; Urabe, M.; Funata, S.; Fukayama, M.; Ushiku, T.; Kaneda, A. DNA Methylation and Genetic Aberrations in Gastric Cancer. Digestion 2021, 102, 25-32. [CrossRef]

119. Woellmer, A.; Hammerschmidt, W. Epstein-Barr Virus and Host Cell Methylation: Regulation of Latency, Replication and Virus Reactivation. Curr. Opin. Virol. 2013, 3, 260-265. [CrossRef]

120. Fernandez, A.F.; Rosales, C.; Lopez-Nieva, P.; Grana, O.; Ballestar, E.; Ropero, S.; Espada, J.; Melo, S.A.; Lujambio, A.; Fraga, M.F.; et al. The Dynamic DNA Methylomes of Double-Stranded DNA Viruses Associated with Human Cancer. Genome Res. 2009, 19, 438-451. [CrossRef]

121. Dhiab, M.B.; Ziadi, S.; Mestiri, S.; Gacem, R.B.; Ksiaa, F.; Trimeche, M. DNA Methylation Patterns in EBV-Positive and EBVNegative Hodgkin Lymphomas. Cell Oncol. 2015, 38, 453-462. [CrossRef]

122. Lee, H.T.; Oh, S.; Ro, D.H.; Yoo, H.; Kwon, Y.W. The Key Role of DNA Methylation and Histone Acetylation in Epigenetics of Atherosclerosis. J. Lipid Atheroscler. 2020, 9, 419-434. [CrossRef]

123. Murata, T.; Kondo, Y.; Sugimoto, A.; Kawashima, D.; Saito, S.; Isomura, H.; Kanda, T.; Tsurumi, T. Epigenetic Histone Modification of Epstein-Barr Virus BZLF1 Promoter during Latency and Reactivation in Raji Cells. J. Virol. 2012, 86, 4752-4761. [CrossRef]

124. Countryman, J.K.; Gradoville, L.; Miller, G. Histone Hyperacetylation Occurs on Promoters of Lytic Cycle Regulatory Genes in Epstein-Barr Virus-Infected Cell Lines Which Are Refractory to Disruption of Latency by Histone Deacetylase Inhibitors. J. Virol. 2008, 82, 4706-4719. [CrossRef]

125. Gallo, A.; Miele, M.; Badami, E.; Conaldi, P.G. Molecular and Cellular Interplay in Virus-Induced Tumors in Solid Organ Recipients. Cell Immunol. 2019, 343, 103770. [CrossRef]

126. Tan, G.; Visser, L.; Tan, L.; Berg, A.; Diepstra, A. The Microenvironment in Epstein—Barr Virus-Associated Malignancies. Pathogens 2018, 7, 40. [CrossRef]

127. Chang, Y.H.; Heo, Y.J.; Cho, J.; Song, S.Y.; Lee, J.; Kim, K.-M. Computational Measurement of Tumor Immune Microenvironment in Gastric Adenocarcinomas. Sci. Rep. 2018, 8, 13887. [CrossRef]

128. Ooft, M.L.; van Ipenburg, J.A.; Braunius, W.W.; Zuur, C.I.; Koljenović, S.; Willems, S.M. Prognostic Role of Tumor Infiltrating Lymphocytes in EBV Positive and EBV Negative Nasopharyngeal Carcinoma. Oral Oncol. 2017, 71, 16-25. [CrossRef]

129. Ferla, V.; Rossi, F.G.; Goldaniga, M.C.; Baldini, L. Biological Difference Between Epstein-Barr Virus Positive and Negative Post-Transplant Lymphoproliferative Disorders and Their Clinical Impact. Front. Oncol. 2020, 10, 506. [CrossRef]

130. Keane, C.; Tobin, J.; Gunawardana, J.; Francis, S.; Gifford, G.; Gabrielli, S.; Gill, A.; Stevenson, W.; Talaulikar, D.; Gould, C.; et al. The Tumour Microenvironment Is Immuno-tolerogenic and a Principal Determinant of Patient Outcome in EBV-positive Diffuse Large B-cell Lymphoma. Eur. J. Haematol. 2019, 103, 200-207. [CrossRef]

131. Marcelis, L.; Tousseyn, T. The Tumor Microenvironment in Post-Transplant Lymphoproliferative Disorders. Cancer Microenviron. 2019, 12, 3-16. [CrossRef]

132. Seliger, B.; Massa, C.; Yang, B.; Bethmann, D.; Kappler, M.; Eckert, A.W.; Wickenhauser, C. Immune Escape Mechanisms and Their Clinical Relevance in Head and Neck Squamous Cell Carcinoma. Int. J. Mol. Sci. 2020, 21, 7032. [CrossRef] 
133. Lechien, J.R.; Seminerio, I.; Descamps, G.; Mat, Q.; Mouawad, F.; Hans, S.; Julieron, M.; Dequanter, D.; Vanderhaegen, T.; Journe, F.; et al. Impact of HPV Infection on the Immune System in Oropharyngeal and Non-Oropharyngeal Squamous Cell Carcinoma: A Systematic Review. Cells 2019, 8, 1061. [CrossRef] [PubMed]

134. Chuang, H.-C.; Lay, J.-D.; Chuang, S.-E.; Hsieh, W.-C.; Chang, Y.; Su, I.-J. Epstein-Barr Virus (EBV) Latent Membrane Protein-1 down-Regulates Tumor Necrosis Factor-Alpha (TNF-Alpha) Receptor-1 and Confers Resistance to TNF-Alpha-Induced Apoptosis in T Cells: Implication for the Progression to T-Cell Lymphoma in EBV-Associated Hemophagocytic Syndrome. Am. J. Pathol. 2007, 170, 1607-1617. [CrossRef] [PubMed]

135. Wong, T.-S.; Chen, S.; Zhang, M.-J.; Chan, J.Y.-W.; Gao, W. Epstein-Barr Virus-Encoded MicroRNA BART7 Downregulates Major Histocompatibility Complex Class I Chain-Related Peptide A and Reduces the Cytotoxicity of Natural Killer Cells to Nasopharyngeal Carcinoma. Oncol. Lett. 2018, 16, 2887-2892. [CrossRef] [PubMed]

136. Agathanggelou, A.; Niedobitek, G.; Chen, R.; Nicholls, J.; Yin, W.; Young, L.S. Expression of Immune Regulatory Molecules in Epstein-Barr Virus-Associated Nasopharyngeal Carcinomas with Prominent Lymphoid Stroma. Evidence for a Functional Interaction between Epithelial Tumor Cells and Infiltrating Lymphoid Cells. Am. J. Pathol. 1995, 147, $1152-1160$.

137. Oda, K.; Tamaru, J.; Takenouchi, T.; Mikata, A.; Nunomura, M.; Saitoh, N.; Sarashina, H.; Nakajima, N. Association of Epstein-Barr Virus with Gastric Carcinoma with Lymphoid Stroma. Am. J. Pathol. 1993, 143, 1063-1071.

138. Ho, H.C.; Kwan, H.C.; Ng, M.H. Immunohistochemistry of Local Immunoglobulin Production in Nasopharyngeal Carcinoma. Br. J. Cancer 1978, 37, 514-519. [CrossRef]

139. Fang, W.; Zhang, J.; Hong, S.; Zhan, J.; Chen, N.; Qin, T.; Tang, Y.; Zhang, Y.; Kang, S.; Zhou, T.; et al. EBV-Driven LMP1 and IFN-Gamma up-Regulate PD-L1 in Nasopharyngeal Carcinoma: Implications for Oncotargeted Therapy. Oncotarget 2014, 5, 12189-12202. [CrossRef]

140. Tsang, C.M.; Deng, W.; Yip, Y.L.; Zeng, M.S.; Lo, K.W.; Tsao, S.W. Epstein-Barr Virus Infection and Persistence in Nasopharyngeal Epithelial Cells. Chin. J. Cancer 2014, 33, 549-555. [CrossRef]

141. Pathmanathan, R.; Prasad, U.; Chandrika, G.; Sadler, R.; Flynn, K.; Raab-Traub, N. Undifferentiated, Nonkeratinizing, and Squamous Cell Carcinoma of the Nasopharynx. Variants of Epstein-Barr Virus-Infected Neoplasia. Am. J. Pathol. 1995, 146, 1355-1367.

142. Küppers, R. B Cells under Influence: Transformation of B Cells by Epstein-Barr Virus. Nat. Rev. Immunol. 2003, 3, 801-812. [CrossRef]

143. Nagpal, P.; Descalzi-Montoya, D.B.; Lodhi, N. The Circuitry of the Tumor Microenvironment in Adult and Pediatric Hodgkin Lymphoma: Cellular Composition, Cytokine Profile, EBV, and Exosomes. Cancer Rep. 2021, 4, e1311. [CrossRef]

144. Hutcheson, R.L.; Chakravorty, A.; Sugden, B. Burkitt Lymphomas Evolve to Escape Dependencies on Epstein-Barr Virus. Front. Cell Infect. Microbiol. 2020, 10, 606412. [CrossRef]

145. Granai, M.; Mundo, L.; Akarca, A.U.; Siciliano, M.C.; Rizvi, H.; Mancini, V.; Onyango, N.; Nyagol, J.; Abinya, N.O.; Maha, I.; et al. Immune Landscape in Burkitt Lymphoma Reveals M2-Macrophage Polarization and Correlation between PD-L1 Expression and Non-Canonical EBV Latency Program. Infect. Agent. Cancer 2020, 15, 28. [CrossRef]

146. Li, S.; Young, K.H.; Medeiros, L.J. Diffuse Large B-Cell Lymphoma. Pathology 2018, 50, 74-87. [CrossRef]

147. Molyneux, E.M.; Rochford, R.; Griffin, B.; Newton, R.; Jackson, G.; Menon, G.; Harrison, C.J.; Israels, T.; Bailey, S. Burkitt's Lymphoma. Lancet 2012, 379, 1234-1244. [CrossRef]

148. Dukers, D.F.; Meij, P.; Vervoort, M.B.H.J.; Vos, W.; Scheper, R.J.; Meijer, C.J.L.M.; Bloemena, E.; Middeldorp, J.M. Direct Immunosuppressive Effects of EBV-Encoded Latent Membrane Protein 1. J. Immunol. 2000, 165, 663-670. [CrossRef]

149. Chen, Y.L. Prognostic Significance of Tumor-Associated Macrophages in Patients with Nasopharyngeal Carcinoma: A MetaAnalysis. Medicine 2020, 99, e21999. [CrossRef]

150. Liu, Y.; He, S.; Wang, X.L.; Peng, W.; Chen, Q.Y.; Chi, D.M.; Chen, J.R.; Han, B.W.; Lin, G.W.; Li, Y.Q.; et al. Tumour Heterogeneity and Intercellular Networks of Nasopharyngeal Carcinoma at Single Cell Resolution. Nat. Commun. 2021, 12, 741. [CrossRef]

151. Zhao, J.; Guo, C.; Xiong, F.; Yu, J.; Ge, J.; Wang, H.; Liao, Q.; Zhou, Y.; Gong, Q.; Xiang, B.; et al. Single Cell RNA-Seq Reveals the Landscape of Tumor and Infiltrating Immune Cells in Nasopharyngeal Carcinoma. Cancer Lett. 2020, 477, 131-143. [CrossRef]

152. Keane, C.; Gould, C.; Jones, K.; Hamm, D.; Talaulikar, D.; Ellis, J.; Vari, F.; Birch, S.; Han, E.; Wood, P.; et al. The T-Cell Receptor Repertoire Influences the Tumor Microenvironment and Is Associated with Survival in Aggressive B-Cell Lymphoma. Clin. Cancer Res. 2017, 23, 1820-1828. [CrossRef]

153. Rieken, J.; Bernard, V.; Witte, H.M.; Peter, W.; Merz, H.; Olschewski, V.; Hertel, L.; Lehnert, H.; Biersack, H.; von Bubnoff, N.; et al Exhaustion of Tumour-Infiltrating T-Cell Receptor Repertoire Diversity Is an Age-Dependent Indicator of Immunological Fitness Independently Predictive of Clinical Outcome in Burkitt Lymphoma. Br. J. Haematol. 2021, 193, 138-149. [CrossRef]

154. Cader, F.Z.; Schackmann, R.C.J.; Hu, X.; Wienand, K.; Redd, R.; Chapuy, B.; Ouyang, J.; Paul, N.; Gjini, E.; Lipschitz, M.; et al. Mass Cytometry of Hodgkin Lymphoma Reveals a CD4(+) Regulatory T-Cell-Rich and Exhausted T-Effector Microenvironment. Blood 2018, 132, 825-836. [CrossRef]

155. O'Connell, P.; Hyslop, S.; Blake, M.K.; Godbehere, S.; Amalfitano, A.; Aldhamen, Y.A. SLAMF7 Signaling Reprograms T Cells toward Exhaustion in the Tumor Microenvironment. J. Immunol. 2021, 206, 193-205. [CrossRef]

156. Zheng, B.J.; Ng, S.P.; Chua, D.T.; Sham, J.S.; Kwong, D.L.; Lam, C.K.; Ng, M.H. Peripheral Gamma Delta T-Cell Deficit in Nasopharyngeal Carcinoma. Int. J. Cancer 2002, 99, 213-217. [CrossRef] 
157. Wu, R.; Sattarzadeh, A.; Rutgers, B.; Diepstra, A.; van den Berg, A.; Visser, L. The Microenvironment of Classical Hodgkin Lymphoma: Heterogeneity by Epstein-Barr Virus Presence and Location within the Tumor. Blood Cancer J. 2016, 6, e417. [CrossRef]

158. Perera, S.M.; Thomas, J.A.; Burke, M.; Crawford, D.H. Analysis of the T-Cell Micro-Environment in Epstein-Barr Virus-Related Post-Transplantation B Lymphoproliferative Disease. J. Pathol. 1998, 184, 177-184. [CrossRef]

159. Baumforth, K.R.; Birgersdotter, A.; Reynolds, G.M.; Wei, W.; Kapatai, G.; Flavell, J.R.; Kalk, E.; Piper, K.; Lee, S.; Machado, L.; et al. Expression of the Epstein-Barr Virus-Encoded Epstein-Barr Virus Nuclear Antigen 1 in Hodgkin's Lymphoma Cells Mediates Up-Regulation of CCL20 and the Migration of Regulatory T Cells. Am. J. Pathol. 2008, 173, 195-204. [CrossRef]

160. Wang, J.; Luo, Y.; Bi, P.; Lu, J.; Wang, F.; Liu, X.; Zhang, B.; Li, X. Mechanisms of Epstein-Barr Virus Nuclear Antigen 1 Favor Tregs Accumulation in Nasopharyngeal Carcinoma. Cancer Med. 2020, 9, 5598-5608. [CrossRef]

161. Cai, T.T.; Ye, S.B.; Liu, Y.N.; He, J.; Chen, Q.Y.; Mai, H.Q.; Zhang, C.X.; Cui, J.; Zhang, X.S.; Busson, P.; et al. LMP1-Mediated Glycolysis Induces Myeloid-Derived Suppressor Cell Expansion in Nasopharyngeal Carcinoma. PLoS Pathog. 2017, 13, e1006503. [CrossRef]

162. Zalfa, C.; Paust, S. Natural Killer Cell Interactions with Myeloid Derived Suppressor Cells in the Tumor Microenvironment and Implications for Cancer Immunotherapy. Front. Immunol. 2021, 12, 633205. [CrossRef]

163. Marini, O.; Spina, C.; Mimiola, E.; Cassaro, A.; Malerba, G.; Todeschini, G.; Perbellini, O.; Scupoli, M.; Carli, G.; Facchinelli, D.; et al. Identification of Granulocytic Myeloid-Derived Suppressor Cells (G-MDSCs) in the Peripheral Blood of Hodgkin and Non-Hodgkin Lymphoma Patients. Oncotarget 2016, 7, 27676-27688. [CrossRef] [PubMed]

164. Gabitass, R.F.; Annels, N.E.; Stocken, D.D.; Pandha, H.A.; Middleton, G.W. Elevated Myeloid-Derived Suppressor Cells in Pancreatic, Esophageal and Gastric Cancer Are an Independent Prognostic Factor and Are Associated with Significant Elevation of the Th2 Cytokine Interleukin-13. Cancer Immunol. Immunother. 2011, 60, 1419-1430. [CrossRef] [PubMed]

165. Li, Z.L.; Ye, S.B.; OuYang, L.Y.; Zhang, H.; Chen, Y.S.; He, J.; Chen, Q.Y.; Qian, C.N.; Zhang, X.S.; Cui, J.; et al. COX-2 Promotes Metastasis in Nasopharyngeal Carcinoma by Mediating Interactions between Cancer Cells and Myeloid-Derived Suppressor Cells. Oncoimmunology 2015, 4, e1044712. [CrossRef] [PubMed]

166. Wang, R.F.; Zhang, L.H.; Shan, L.H.; Sun, W.G.; Chai, C.C.; Wu, H.M.; Ibla, J.C.; Wang, L.F.; Liu, J.R. Effects of the Fibroblast Activation Protein on the Invasion and Migration of Gastric Cancer. Exp. Mol. Pathol. 2013, 95, 350-356. [CrossRef]

167. Chen, J.; Yang, P.; Xiao, Y.; Zhang, Y.; Liu, J.; Xie, D.; Cai, M.; Zhang, X. Overexpression of Alpha-Sma-Positive Fibroblasts (CAFs) in Nasopharyngeal Carcinoma Predicts Poor Prognosis. J. Cancer 2017, 8, 3897-3902. [CrossRef]

168. Alvaro, T.; Lejeune, M.; Garcia, J.F.; Salvado, M.T.; Lopez, C.; Bosch, R.; Jaen, J.; Escriva, P.; Pons, L.E. Tumor-Infiltrated Immune Response Correlates with Alterations in the Apoptotic and Cell Cycle Pathways in Hodgkin and Reed-Sternberg Cells. Clin. Cancer Res. 2008, 14, 685-691. [CrossRef]

169. Song, H.; Park, H.; Kim, J.; Park, G.; Kim, Y.S.; Kim, S.M.; Kim, D.; Seo, S.K.; Lee, H.K.; Cho, D.; et al. IDO Metabolite Produced by EBV-Transformed B Cells Inhibits Surface Expression of NKG2D in NK Cells via the c-Jun N-Terminal Kinase (JNK) Pathway. Immunol. Lett. 2011, 136, 187-193. [CrossRef]

170. Lakhdar, M.; Oueslati, R.; Ellouze, R.; Thameur, H.; Cammoun, M.; Khedhiri, N.; Kastally, R. High Interferon Titer and Defective NK-Cell Activity in the Circulation of Nasopharyngeal Carcinoma Patients. Int. J. Cancer 1989, 43, 543-548. [CrossRef]

171. Liou, A.K.; Soon, G.; Tan, L.; Peng, Y.; Cher, B.M.; Goh, B.C.; Wang, S.; Lim, C.M. Elevated IL18 Levels in Nasopharyngeal Carcinoma Induced PD-1 Expression on NK Cells in TILS Leading to Poor Prognosis. Oral Oncol. 2020, 104, 104616. [CrossRef]

172. Jia, X.; Guo, T.; Li, Z.; Zhang, M.; Feng, Y.; Dong, B.; Li, Z.; Hu, Y.; Li, Z.; Xing, X.; et al. Clinicopathological and Immunomicroenvironment Characteristics of Epstein-Barr Virus-Associated Gastric Cancer in a Chinese Population. Front. Oncol. 2020, 10, 586752. [CrossRef]

173. Ghasemi, F.; Gameiro, S.F.; Tessier, T.M.; Maciver, A.H.; Mymryk, J.S. High Levels of Class I Major Histocompatibility Complex MRNA Are Present in Epstein-Barr Virus-Associated Gastric Adenocarcinomas. Cells 2020, 9, 499. [CrossRef]

174. Eidenschenk, C.; Dunne, J.; Jouanguy, E.; Fourlinnie, C.; Gineau, L.; Bacq, D.; McMahon, C.; Smith, O.; Casanova, J.L.; Abel, L.; et al. A Novel Primary Immunodeficiency with Specific Natural-Killer Cell Deficiency Maps to the Centromeric Region of Chromosome 8. Am. J. Hum. Genet. 2006, 78, 721-727. [CrossRef]

175. Chen, Q.; Hu, W.; Xiong, H.; Ying, S.; Ruan, Y.; Wu, B.; Lu, H. Changes in Plasma EBV-DNA and Immune Status in Patients with Nasopharyngeal Carcinoma after Treatment with Intensity-Modulated Radiotherapy. Diagn. Pathol. 2019, 14, 23. [CrossRef]

176. Derks, S.; de Klerk, L.K.; Xu, X.; Fleitas, T.; Liu, K.X.; Liu, Y.; Dietlein, F.; Margolis, C.; Chiaravalli, A.M.; Da Silva, A.C.; et al. Characterizing Diversity in the Tumor-Immune Microenvironment of Distinct Subclasses of Gastroesophageal Adenocarcinomas. Ann. Oncol. 2020, 31, 1011-1020. [CrossRef]

177. Lanford, R.E.; Jacob, J.R.; Butel, J.S. Genomic Organization of the Simian Virus 40-Adenovirus 7 Hybrid Virus, PARA(CT), That Encodes a Nuclear Transport Defective Simian Virus 40 T Antigen. Virology 1986, 155, 271-276. [CrossRef]

178. Cho, J.; Chang, Y.H.; Heo, Y.J.; Kim, S.; Kim, N.K.D.; Park, J.O.; Kang, W.K.; Lee, J.; Kim, K.-M. Four Distinct Immune Microenvironment Subtypes in Gastric Adenocarcinoma with Special Reference to Microsatellite Instability. ESMO Open 2018, 3 , e000326. [CrossRef]

179. Hinata, M.; Kunita, A.; Abe, H.; Morishita, Y.; Sakuma, K.; Yamashita, H.; Seto, Y.; Ushiku, T.; Fukayama, M. Exosomes of Epstein-Barr Virus-Associated Gastric Carcinoma Suppress Dendritic Cell Maturation. Microorganisms 2020, 8, 1776. [CrossRef]

180. Satoh, T.; Wada, R.; Yajima, N.; Imaizumi, T.; Yagihashi, S. Tumor Microenvironment and RIG-I Signaling Molecules in Epstein Barr Virus-Positive and -Negative Classical Hodgkin Lymphoma of the Elderly. J. Clin. Exp. Hematop. 2014, 54, 75-84. [CrossRef] 
181. Karihtala, K.; Leivonen, S.K.; Bruck, O.; Karjalainen-Lindsberg, M.L.; Mustjoki, S.; Pellinen, T.; Leppa, S. Prognostic Impact of Tumor-Associated Macrophages on Survival Is Checkpoint Dependent in Classical Hodgkin Lymphoma. Cancers 2020, $12,877$. [CrossRef]

182. Fu, L.; Xie, J.; Lin, J.; Wang, J.; Wei, N.; Huang, D.; Wang, T.; Shen, J.; Zhou, X.; Wang, Z. Monomorphic Post-Transplant Lymphoproliferative Disorder After Kidney Transplantation and Hematopoietic Stem Cell Transplantation: Clinicopathological Characteristics, Treatments and Prognostic Factors. Indian J. Hematol. Blood Transfus. 2017, 33, 492-499. [CrossRef]

183. Li, X.; Zhang, W. Expression of PD-L1 in EBV-Associated Malignancies. Int. Immunopharmacol. 2021, 95, 107553. [CrossRef] [PubMed]

184. Weinstein, A.M.; Storkus, W.J. Therapeutic Lymphoid Organogenesis in the Tumor Microenvironment. Adv. Cancer Res. 2015, 128, 197-233. [CrossRef] [PubMed]

185. Gong, L.P.; Chen, J.N.; Xiao, L.; He, Q.; Feng, Z.Y.; Zhang, Z.G.; Liu, J.P.; Wei, H.B.; Shao, C.K. The Implication of Tumor-Infiltrating Lymphocytes in Epstein-Barr Virus-Associated Gastric Carcinoma. Hum. Pathol. 2019, 85, 82-91. [CrossRef] [PubMed]

186. Tosato, G.; Tanner, J.; Jones, K.D.; Revel, M.; Pike, S.E. Identification of Interleukin-6 as an Autocrine Growth Factor for Epstein-Barr Virus-Immortalized B Cells. J. Virol. 1990, 64, 3033-3041. [CrossRef]

187. Zhang, G.; Tsang, C.M.; Deng, W.; Yip, Y.L.; Lui, V.W.; Wong, S.C.; Cheung, A.L.; Hau, P.M.; Zeng, M.; Lung, M.L.; et al. Enhanced IL-6/IL-6R Signaling Promotes Growth and Malignant Properties in EBV-Infected Premalignant and Cancerous Nasopharyngeal Epithelial Cells. PLoS ONE 2013, 8, e62284. [CrossRef]

188. Ren, Y.; Yang, J.; Li, M.; Huang, N.; Chen, Y.; Wu, X.; Wang, X.; Qiu, S.; Wang, H.; Li, X. Viral IL-10 Promotes Cell Proliferation and Cell Cycle Progression via JAK2/STAT3 Signaling Pathway in Nasopharyngeal Carcinoma Cells. Biotechnol. Appl. Biochem. 2020, 67, 929-938. [CrossRef]

189. Li, X.J.; Peng, L.X.; Shao, J.Y.; Lu, W.H.; Zhang, J.X.; Chen, S.; Chen, Z.Y.; Xiang, Y.Q.; Bao, Y.N.; Zheng, F.J.; et al. As an Independent Unfavorable Prognostic Factor, IL-8 Promotes Metastasis of Nasopharyngeal Carcinoma through Induction of Epithelial-Mesenchymal Transition and Activation of AKT Signaling. Carcinogenesis 2012, 33, 1302-1309. [CrossRef]

190. Roncarolo, M.G.; Bacchetta, R.; Bordignon, C.; Narula, S.; Levings, M.K. Type 1 T Regulatory Cells. Immunol. Rev. 2001, 182, 68-79. [CrossRef]

191. De Waal Malefyt, R.; Haanen, J.; Spits, H.; Roncarolo, M.G.; te Velde, A.; Figdor, C.; Johnson, K.; Kastelein, R.; Yssel, H.; de Vries, J.E. Interleukin 10 (IL-10) and Viral IL-10 Strongly Reduce Antigen-Specific Human T Cell Proliferation by Diminishing the Antigen-Presenting Capacity of Monocytes via Downregulation of Class II Major Histocompatibility Complex Expression. J. Exp. Med. 1991, 174, 915-924. [CrossRef]

192. Marshall, N.A.; Vickers, M.A.; Barker, R.N. Regulatory T Cells Secreting IL-10 Dominate the Immune Response to EBV Latent Membrane Protein 1. J. Immunol. 2003, 170, 6183-6189. [CrossRef]

193. Nappo, G.; Handle, F.; Santer, F.R.; McNeill, R.V.; Seed, R.I.; Collins, A.T.; Morrone, G.; Culig, Z.; Maitland, N.J.; Erb, H.H.H. The Immunosuppressive Cytokine Interleukin-4 Increases the Clonogenic Potential of Prostate Stem-like Cells by Activation of STAT6 Signalling. Oncogenesis 2017, 6, e342. [CrossRef]

194. Teichmann, M.; Meyer, B.; Beck, A.; Niedobitek, G. Expression of the Interferon-Inducible Chemokine IP-10 (CXCL10), a Chemokine with Proposed Anti-Neoplastic Functions, in Hodgkin Lymphoma and Nasopharyngeal Carcinoma. J. Pathol. 2005, 206, 68-75. [CrossRef]

195. Liu, M.; Guo, S.; Stiles, J.K. The Emerging Role of CXCL10 in Cancer (Review). Oncol. Lett. 2011, 2, 583-589. [CrossRef]

196. Wang, H.; Zhou, L.; Yang, Y.; Luo, B. Screening and Identification of Key Genes in EBV-Associated Gastric Carcinoma Based on Bioinformatics Analysis. Pathol. Res. Pract. 2021, 222, 153439. [CrossRef]

197. Piovan, E.; Tosello, V.; Indraccolo, S.; Cabrelle, A.; Baesso, I.; Trentin, L.; Zamarchi, R.; Tamamura, H.; Fujii, N.; Semenzato, G.; et al. Chemokine Receptor Expression in EBV-Associated Lymphoproliferation in Hu/SCID Mice: Implications for CXCL12/CXCR4 Axis in Lymphoma Generation. Blood 2005, 105, 931-939. [CrossRef]

198. Morris, M.A. Cancer-Associated Fibroblasts in Undifferentiated Nasopharyngeal Carcinoma: A Putative Role for the EBV-Encoded Oncoprotein, LMP1. Pathogens 2019, 9, 8. [CrossRef]

199. Li, J.; Zhang, X.S.; Xie, D.; Deng, H.X.; Gao, Y.F.; Chen, Q.Y.; Huang, W.L.; Masucci, M.G.; Zeng, Y.X. Expression of ImmuneRelated Molecules in Primary EBV-Positive Chinese Nasopharyngeal Carcinoma: Associated with Latent Membrane Protein 1 (LMP1) Expression. Cancer Biol. Ther. 2007, 6, 1997-2004. [CrossRef]

200. Pachnia, D.; Drop, B.; Dworzanska, A.; Kliszczewska, E.; Polz-Dacewicz, M. Transforming Growth Factor-Beta, Interleukin-10, and Serological Markers in EBV-Associated Gastric Carcinoma. Anticancer Res. 2017, 37, 4853-4858. [CrossRef]

201. Beck, A.; Pazolt, D.; Grabenbauer, G.G.; Nicholls, J.M.; Herbst, H.; Young, L.S.; Niedobitek, G. Expression of Cytokine and Chemokine Genes in Epstein-Barr Virus-Associated Nasopharyngeal Carcinoma: Comparison with Hodgkin's Disease. J. Pathol. 2001, 194, 145-151. [CrossRef]

202. Birkeland, S.A.; Bendtzen, K.; Moller, B.; Hamilton-Dutoit, S.; Andersen, H.K. Interleukin-10 and Posttransplant Lymphoproliferative Disorder after Kidney Transplantation. Transplantation 1999, 67, 876-881. [CrossRef]

203. Cortes, J.; Kurzrock, R. Interleukin-10 in Non-Hodgkin's Lymphoma. Leukemia Lymphoma 1997, 26, 251-259. [CrossRef]

204. Herling, M.; Rassidakis, G.Z.; Medeiros, L.J.; Vassilakopoulos, T.P.; Kliche, K.O.; Nadali, G.; Viviani, S.; Bonfante, V.; Giardini, R.; Chilosi, M.; et al. Expression of Epstein-Barr Virus Latent Membrane Protein-1 in Hodgkin and Reed-Sternberg Cells of Classical 
Hodgkin's Lymphoma: Associations with Presenting Features, Serum Interleukin 10 Levels, and Clinical Outcome. Clin. Cancer Res. 2003, 9, 2114-2120.

205. Sato, T.; Terai, M.; Tamura, Y.; Alexeev, V.; Mastrangelo, M.J.; Selvan, S.R. Interleukin 10 in the Tumor Microenvironment: A Target for Anticancer Immunotherapy. Immunol. Res. 2011, 51, 170-182. [CrossRef]

206. Gao, L.; Han, H.; Wang, H.; Cao, L.; Feng, W.H. IL-10 Knockdown with SiRNA Enhances the Efficacy of Doxorubicin Chemotherapy in EBV-Positive Tumors by Inducing Lytic Cycle via PI3K/P38 MAPK/NF-KB Pathway. Cancer Lett. 2019, 462, 12-22. [CrossRef]

207. Kis, L.L.; Gerasimcik, N.; Salamon, D.; Persson, E.K.; Nagy, N.; Klein, G.; Severinson, E.; Klein, E. STAT6 Signaling Pathway Activated by the Cytokines IL-4 and IL-13 Induces Expression of the Epstein-Barr Virus-Encoded Protein LMP-1 in Absence of EBNA-2: Implications for the Type II EBV Latent Gene Expression in Hodgkin Lymphoma. Blood 2011, 117, 165-174. [CrossRef] [PubMed]

208. Fior, R.; Vita, N.; Raphael, M.; Minty, A.; Maillot, M.C.; Crevon, M.C.; Caput, D.; Biberfeld, P.; Ferrara, P.; Galanaud, P.; et al. Interleukin-13 Gene Expression by Malignant and EBV-Transformed Human B Lymphocytes. Eur. Cytokine Netw. 1994, 5, 593-600. [PubMed]

209. Bailey, S.R.; Nelson, M.H.; Himes, R.A.; Li, Z.; Mehrotra, S.; Paulos, C.M. Th17 Cells in Cancer: The Ultimate Identity Crisis. Front. Immunol. 2014, 5, 276. [CrossRef] [PubMed]

210. Lunardi, S.; Lim, S.Y.; Muschel, R.J.; Brunner, T.B. IP-10/CXCL10 Attracts Regulatory T Cells: Implication for Pancreatic Cancer. Oncoimmunology 2015, 4, e1027473. [CrossRef]

211. Orimo, A.; Gupta, P.B.; Sgroi, D.C.; Arenzana-Seisdedos, F.; Delaunay, T.; Naeem, R.; Carey, V.J.; Richardson, A.L.; Weinberg, R.A. Stromal Fibroblasts Present in Invasive Human Breast Carcinomas Promote Tumor Growth and Angiogenesis through Elevated SDF-1/CXCL12 Secretion. Cell 2005, 121, 335-348. [CrossRef]

212. Teng, F.; Tian, W.Y.; Wang, Y.M.; Zhang, Y.F.; Guo, F.; Zhao, J.; Gao, C.; Xue, F.X. Cancer-Associated Fibroblasts Promote the Progression of Endometrial Cancer via the SDF-1/CXCR4 Axis. J. Hematol. Oncol. 2016, 9, 8. [CrossRef]

213. Wang, S.; Ma, N.; Kawanishi, S.; Hiraku, Y.; Oikawa, S.; Xie, Y.; Zhang, Z.; Huang, G.; Murata, M. Relationships of Alpha-SMAPositive Fibroblasts and SDF-1-Positive Tumor Cells with Neoangiogenesis in Nasopharyngeal Carcinoma. Biomed. Res. Int. 2014, 2014, 507353. [CrossRef]

214. Wang, N.; Wu, Q.L.; Fang, Y.; Mai, H.Q.; Zeng, M.S.; Shen, G.P.; Hou, J.H.; Zeng, Y.X. Expression of Chemokine Receptor CXCR4 in Nasopharyngeal Carcinoma: Pattern of Expression and Correlation with Clinical Outcome. J. Transl. Med. 2005, 3, 26. [CrossRef]

215. Wang, W.; Zhang, Y.; Liu, W.; Zhang, X.; Xiao, H.; Zhao, M.; Luo, B. CXCR4 Induces Cell Autophagy and Maintains EBV Latent Infection in EBVaGC. Theranostics 2020, 10, 11549-11561. [CrossRef]

216. Zhou, Y.; Xia, L.; Lin, J.; Wang, H.; Oyang, L.; Tan, S.; Tian, Y.; Su, M.; Wang, H.; Cao, D.; et al. Exosomes in Nasopharyngeal Carcinoma. J. Cancer 2018, 9, 767-777. [CrossRef]

217. Chen, X.; Li, D.; Huang, Z.; Zhong, S.; Cai, L. Effect of Exosomes Derived from Human Epstein-Barr Virus-Positive Nasopharyngeal Carcinoma Cells on Lymphangiogenesis and Lymph Node Metastasis. Nan Fang Yi Ke Xue Xue Bao 2020, 40, 1776-1783. [CrossRef]

218. Bobrie, A.; Colombo, M.; Raposo, G.; Thery, C. Exosome Secretion: Molecular Mechanisms and Roles in Immune Responses. Traffic 2011, 12, 1659-1668. [CrossRef]

219. Doyle, L.M.; Wang, M.Z. Overview of Extracellular Vesicles, Their Origin, Composition, Purpose, and Methods for Exosome Isolation and Analysis. Cells 2019, 8, 727. [CrossRef]

220. Uccini, S.; Al-Jadiry, M.F.; Pepe, G.; Pasquini, A.; Alsaadawi, A.R.; Al-Hadad, S.A.; Di Napoli, A.; Tripodo, C.; Ruco, L. Follicular Dendritic Cells Display Microvesicle-Associated LMP1 in Reactive Germinal Centers of EBV+ Classic Hodgkin Lymphoma. Virchows Arch. 2019, 475, 175-180. [CrossRef]

221. Keryer-Bibens, C.; Pioche-Durieu, C.; Villemant, C.; Souquere, S.; Nishi, N.; Hirashima, M.; Middeldorp, J.; Busson, P. Exosomes Released by EBV-Infected Nasopharyngeal Carcinoma Cells Convey the Viral Latent Membrane Protein 1 and the Immunomodulatory Protein Galectin 9. BMC Cancer 2006, 6, 283. [CrossRef]

222. Villani, C.; Nobili, F.; Stentella, P.; Pace, S. The Viral Lesion (HPV) of the Lower Genital Tract in Teen Agers: Clinical and Therapeutic Aspects. Eur. J. Gynaecol. Oncol. 1989, 10, 267-271.

223. George, J.T.; Levine, H. Implications of Tumor-Immune Coevolution on Cancer Evasion and Optimized Immunotherapy. Trends Cancer 2021, 7, 373-383. [CrossRef]

224. Montironi, C.; Munoz-Pinedo, C.; Eldering, E. Hematopoietic versus Solid Cancers and T Cell Dysfunction: Looking for Similarities and Distinctions. Cancers 2021, 13, 284. [CrossRef]

225. Jasinski-Bergner, S.; Mandelboim, O.; Seliger, B. Molecular Mechanisms of Human Herpes Viruses Inferring with Host Immune Surveillance. J. Immunother. Cancer 2020, 8, e000841. [CrossRef]

226. Ressing, M.E.; van Gent, M.; Gram, A.M.; Hooykaas, M.J.; Piersma, S.J.; Wiertz, E.J. Immune Evasion by Epstein-Barr Virus. Curr. Top. Microbiol. Immunol. 2015, 391, 355-381. [CrossRef]

227. Joos, S.; Kupper, M.; Ohl, S.; von Bonin, F.; Mechtersheimer, G.; Bentz, M.; Marynen, P.; Moller, P.; Pfreundschuh, M.; Trumper, L.; et al. Genomic Imbalances Including Amplification of the Tyrosine Kinase Gene JAK2 in CD30+ Hodgkin Cells. Cancer Res. 2000, $60,549-552$. 
228. Van Roosbroeck, K.; Cox, L.; Tousseyn, T.; Lahortiga, I.; Gielen, O.; Cauwelier, B.; De Paepe, P.; Verhoef, G.; Marynen, P.; Vandenberghe, P.; et al. JAK2 Rearrangements, Including the Novel SEC31A-JAK2 Fusion, Are Recurrent in Classical Hodgkin Lymphoma. Blood 2011, 117, 4056-4064. [CrossRef]

229. Polprasert, C.; Takeuchi, Y.; Makishima, H.; Wudhikarn, K.; Kakiuchi, N.; Tangnuntachai, N.; Assanasen, T.; Sitthi, W.; Muhamad, H.; Lawasut, P.; et al. Frequent Mutations in HLA and Related Genes in Extranodal NK/T Cell Lymphomas. Leukemia Lymphoma 2021, 62, 95-103. [CrossRef]

230. Kataoka, K.; Miyoshi, H.; Sakata, S.; Dobashi, A.; Couronne, L.; Kogure, Y.; Sato, Y.; Nishida, K.; Gion, Y.; Shiraishi, Y.; et al. Frequent Structural Variations Involving Programmed Death Ligands in Epstein-Barr Virus-Associated Lymphomas. Leukemia 2019, 33, 1687-1699. [CrossRef] [PubMed]

231. Jasinski-Bergner, S.; Mandelboim, O.; Seliger, B. The Role of MicroRNAs in the Control of Innate Immune Response in Cancer. J. Natl. Cancer Inst. 2014, 106, dju257. [CrossRef] [PubMed]

232. Lazaridou, M.F.; Gonschorek, E.; Massa, C.; Friedrich, M.; Handke, D.; Mueller, A.; Jasinski-Bergner, S.; Dummer, R.; Koelblinger, P.; Seliger, B. Identification of MiR-200a-5p Targeting the Peptide Transporter TAP1 and Its Association with the Clinical Outcome of Melanoma Patients. Oncoimmunology 2020, 9, 1774323. [CrossRef] [PubMed]

233. Hislop, A.D.; Ressing, M.E.; van Leeuwen, D.; Pudney, V.A.; Horst, D.; Koppers-Lalic, D.; Croft, N.P.; Neefjes, J.J.; Rickinson, A.B.; Wiertz, E.J.H.J. A CD8+ T Cell Immune Evasion Protein Specific to Epstein-Barr Virus and Its Close Relatives in Old World Primates. J. Exp. Med. 2007, 204, 1863-1873. [CrossRef]

234. Zuo, J.; Currin, A.; Griffin, B.D.; Shannon-Lowe, C.; Thomas, W.A.; Ressing, M.E.; Wiertz, E.J.H.J.; Rowe, M. The Epstein-Barr Virus G-Protein-Coupled Receptor Contributes to Immune Evasion by Targeting MHC Class I Molecules for Degradation. PLoS Pathog. 2009, 5, e1000255. [CrossRef]

235. Rowe, M.; Glaunsinger, B.; van Leeuwen, D.; Zuo, J.; Sweetman, D.; Ganem, D.; Middeldorp, J.; Wiertz, E.J.H.J.; Ressing, M.E. Host Shutoff during Productive Epstein-Barr Virus Infection Is Mediated by BGLF5 and May Contribute to Immune Evasion. Proc. Natl. Acad. Sci. USA 2007, 104, 3366-3371. [CrossRef]

236. Quinn, L.L.; Williams, L.R.; White, C.; Forrest, C.; Zuo, J.; Rowe, M. The Missing Link in Epstein-Barr Virus Immune Evasion: The BDLF3 Gene Induces Ubiquitination and Downregulation of Major Histocompatibility Complex Class I (MHC-I) and MHC-II. J. Virol. 2016, 90, 356-367. [CrossRef]

237. Griffin, B.D.; Gram, A.M.; Mulder, A.; Van Leeuwen, D.; Claas, F.H.; Wang, F.; Ressing, M.E.; Wiertz, E. EBV BILF1 Evolved to Downregulate Cell Surface Display of a Wide Range of HLA Class I Molecules through Their Cytoplasmic Tail. J. Immunol. 2013, 190, 1672-1684. [CrossRef]

238. Fares, S.; Spiess, K.; Olesen, E.T.B.; Zuo, J.; Jackson, S.; Kledal, T.N.; Wills, M.R.; Rosenkilde, M.M. Distinct Roles of Extracellular Domains in the Epstein-Barr Virus-Encoded BILF1 Receptor for Signaling and Major Histocompatibility Complex Class I Downregulation. mBio 2019, 10, e01707-18. [CrossRef]

239. Levitskaya, J.; Sharipo, A.; Leonchiks, A.; Ciechanover, A.; Masucci, M.G. Inhibition of Ubiquitin/Proteasome-Dependent Protein Degradation by the Gly-Ala Repeat Domain of the Epstein-Barr Virus Nuclear Antigen 1. Proc. Natl. Acad. Sci. USA 1997, 94, 12616-12621. [CrossRef]

240. Wycisk, A.I.; Lin, J.; Loch, S.; Hobohm, K.; Funke, J.; Wieneke, R.; Koch, J.; Skach, W.R.; Mayerhofer, P.U.; Tampe, R. Epstein-Barr Viral BNLF2a Protein Hijacks the Tail-Anchored Protein Insertion Machinery to Block Antigen Processing by the Transport Complex TAP. J. Biol. Chem. 2011, 286, 41402-41412. [CrossRef]

241. Horst, D.; van Leeuwen, D.; Croft, N.P.; Garstka, M.A.; Hislop, A.D.; Kremmer, E.; Rickinson, A.B.; Wiertz, E.J.; Ressing, M.E. Specific Targeting of the EBV Lytic Phase Protein BNLF2a to the Transporter Associated with Antigen Processing Results in Impairment of HLA Class I-Restricted Antigen Presentation. J. Immunol. 2009, 182, 2313-2324. [CrossRef]

242. Mrozek-Gorska, P.; Buschle, A.; Pich, D.; Schwarzmayr, T.; Fechtner, R.; Scialdone, A.; Hammerschmidt, W. Epstein-Barr Virus Reprograms Human B Lymphocytes Immediately in the Prelatent Phase of Infection. Proc. Natl. Acad. Sci. USA 2019, 116, 16046-16055. [CrossRef]

243. Li, Q.; Cohen, J.I. Epstein-Barr Virus and the Human Leukocyte Antigen Complex. Curr. Clin. Microbiol. Rep. $2019,6,175-181$. [CrossRef]

244. Albanese, M.; Tagawa, T.; Bouvet, M.; Maliqi, L.; Lutter, D.; Hoser, J.; Hastreiter, M.; Hayes, M.; Sugden, B.; Martin, L.; et al. Epstein-Barr Virus MicroRNAs Reduce Immune Surveillance by Virus-Specific CD8+ T Cells. Proc. Natl. Acad. Sci. USA 2016, 113, E6467-E6475. [CrossRef]

245. Van Gent, M.; Gram, A.M.; Boer, I.G.J.; Geerdink, R.J.; Lindenbergh, M.F.S.; Lebbink, R.J.; Wiertz, E.J.; Ressing, M.E. Silencing the Shutoff Protein of Epstein-Barr Virus in Productively Infected B Cells Points to (Innate) Targets for Immune Evasion. J. Gen. Virol. 2015, 96, 858-865. [CrossRef]

246. Ressing, M.E.; van Leeuwen, D.; Verreck, F.A.; Keating, S.; Gomez, R.; Franken, K.L.; Ottenhoff, T.H.; Spriggs, M.; Schumacher, T.N.; Hutt-Fletcher, L.M.; et al. Epstein-Barr Virus Gp42 Is Posttranslationally Modified to Produce Soluble Gp42 That Mediates HLA Class II Immune Evasion. J. Virol. 2005, 79, 841-852. [CrossRef]

247. Ressing, M.E.; Keating, S.E.; van Leeuwen, D.; Koppers-Lalic, D.; Pappworth, I.Y.; Wiertz, E.J.; Rowe, M. Impaired Transporter Associated with Antigen Processing-Dependent Peptide Transport during Productive EBV Infection. J. Immunol. 2005, 174, 6829-6838. [CrossRef] 
248. Li, D.; Qian, L.; Chen, C.; Shi, M.; Yu, M.; Hu, M.; Song, L.; Shen, B.; Guo, N. Down-Regulation of MHC Class II Expression through Inhibition of CIITA Transcription by Lytic Transactivator Zta during Epstein-Barr Virus Reactivation. J. Immunol. 2009, 182, 1799-1809. [CrossRef]

249. Kanegane, H.; Wakiguchi, H.; Kanegane, C.; Kurashige, T.; Tosato, G. Viral Interleukin-10 in Chronic Active Epstein-Barr Virus Infection. J. Infect. Dis. 1997, 176, 254-257. [CrossRef]

250. Zeidler, R.; Eissner, G.; Meissner, P.; Uebel, S.; Tampe, R.; Lazis, S.; Hammerschmidt, W. Downregulation of TAP1 in B Lymphocytes by Cellular and Epstein-Barr Virus-Encoded Interleukin-10. Blood 1997, 90, 2390-2397. [CrossRef]

251. Samanta, M.; Iwakiri, D.; Takada, K. Epstein-Barr Virus-Encoded Small RNA Induces IL-10 through RIG-I-Mediated IRF-3 Signaling. Oncogene 2008, 27, 4150-4160. [CrossRef]

252. Bukur, J.; Jasinski, S.; Seliger, B. The Role of Classical and Non-Classical HLA Class I Antigens in Human Tumors. Semin. Cancer Biol. 2012, 22, 350-358. [CrossRef]

253. Friedrich, M.; Jasinski-Bergner, S.; Lazaridou, M.F.; Subbarayan, K.; Massa, C.; Tretbar, S.; Mueller, A.; Handke, D.; Biehl, K.; Bukur, J.; et al. Tumor-Induced Escape Mechanisms and Their Association with Resistance to Checkpoint Inhibitor Therapy. Cancer Immunol. Immunother. 2019, 68, 1689-1700. [CrossRef] [PubMed]

254. Gazit, E.; Sherf, M.; Balbin, E.; Muratov, A.; Goldstein, I.; Loewenthal, R. HLA-G Expression Is Induced in Epstein-Barr Virus-Transformed B-Cell Lines by Culture Conditions. Hum. Immunol. 2007, 68, 463-468. [CrossRef] [PubMed]

255. Dunker, K.; Schlaf, G.; Bukur, J.; Altermann, W.W.; Handke, D.; Seliger, B. Expression and Regulation of Non-Classical HLA-G in Renal Cell Carcinoma. Tissue Antigens 2008, 72, 137-148. [CrossRef] [PubMed]

256. Diepstra, A.; Poppema, S.; Boot, M.; Visser, L.; Nolte, I.M.; Niens, M.; Te Meerman, G.J.; van den Berg, A. HLA-G Protein Expression as a Potential Immune Escape Mechanism in Classical Hodgkin's Lymphoma. Tissue Antigens 2008, 71, $219-226$. [CrossRef]

257. Seliger, B.; Jasinski-Bergner, S.; Quandt, D.; Stoehr, C.; Bukur, J.; Wach, S.; Legal, W.; Taubert, H.; Wullich, B.; Hartmann, A. HLA-E Expression and Its Clinical Relevance in Human Renal Cell Carcinoma. Oncotarget 2016, 7, 67360-67372. [CrossRef]

258. Braud, V.M.; Allan, D.S.; O'Callaghan, C.A.; Soderstrom, K.; D’Andrea, A.; Ogg, G.S.; Lazetic, S.; Young, N.T.; Bell, J.I.; Phillips, J.H.; et al. HLA-E Binds to Natural Killer Cell Receptors CD94/NKG2A, B and C. Nature 1998, 391, 795-799. [CrossRef]

259. Mbiribindi, B.; Pena, J.K.; Arvedson, M.P.; Moreno Romero, C.; McCarthy, S.R.; Hatton, O.L.; Esquivel, C.O.; Martinez, O.M.; Krams, S.M. Epstein-Barr Virus Peptides Derived from Latent Cycle Proteins Alter NKG2A + NK Cell Effector Function. Sci. Rep. 2020, 10, 19973. [CrossRef]

260. Lee, N.; Geraghty, D.E. HLA-F Surface Expression on B Cell and Monocyte Cell Lines Is Partially Independent from Tapasin and Completely Independent from TAP. J. Immunol. 2003, 171, 5264-5271. [CrossRef]

261. Saito, R.; Abe, H.; Kunita, A.; Yamashita, H.; Seto, Y.; Fukayama, M. Overexpression and Gene Amplification of PD-L1 in Cancer Cells and PD-L1(+) Immune Cells in Epstein-Barr Virus-Associated Gastric Cancer: The Prognostic Implications. Mod. Pathol. 2017, 30, 427-439. [CrossRef]

262. Chen, B.J.; Chapuy, B.; Ouyang, J.; Sun, H.H.; Roemer, M.G.; Xu, M.L.; Yu, H.; Fletcher, C.D.; Freeman, G.J.; Shipp, M.A.; et al. PD-L1 Expression Is Characteristic of a Subset of Aggressive B-Cell Lymphomas and Virus-Associated Malignancies. Clin. Cancer Res. 2013, 19, 3462-3473. [CrossRef]

263. Menter, T.; Tzankov, A. Mechanisms of Immune Evasion and Immune Modulation by Lymphoma Cells. Front. Oncol. 2018, 8, 54. [CrossRef]

264. Lin, N.; Song, Y.; Zhu, J. Immune Checkpoint Inhibitors in Malignant Lymphoma: Advances and Perspectives. Chin. J. Cancer Res. 2020, 32, 303-318. [CrossRef]

265. Bi, X.W.; Wang, H.; Zhang, W.W.; Wang, J.H.; Liu, W.J.; Xia, Z.J.; Huang, H.Q.; Jiang, W.Q.; Zhang, Y.J.; Wang, L. PD-L1 Is Upregulated by EBV-Driven LMP1 through NF-KappaB Pathway and Correlates with Poor Prognosis in Natural Killer/T-Cell Lymphoma. J. Hematol. Oncol. 2016, 9, 109. [CrossRef]

266. Anastasiadou, E.; Stroopinsky, D.; Alimperti, S.; Jiao, A.L.; Pyzer, A.R.; Cippitelli, C.; Pepe, G.; Severa, M.; Rosenblatt, J.; Etna, M.P.; et al. Epstein-Barr Virus-Encoded EBNA2 Alters Immune Checkpoint PD-L1 Expression by Downregulating MiR-34a in B-Cell Lymphomas. Leukemia 2019, 33, 132-147. [CrossRef]

267. Cristino, A.S.; Nourse, J.; West, R.A.; Sabdia, M.B.; Law, S.C.; Gunawardana, J.; Vari, F.; Mujaj, S.; Thillaiyampalam, G.; Snell, C.; et al. EBV MicroRNA-BHRF1-2-5p Targets the 3'UTR of Immune Checkpoint Ligands PD-L1 and PD-L2. Blood 2019, 134, 2261-2270. [CrossRef]

268. Gandhi, M.K.; Lambley, E.; Duraiswamy, J.; Dua, U.; Smith, C.; Elliott, S.; Gill, D.; Marlton, P.; Seymour, J.; Khanna, R. Expression of LAG-3 by Tumor-Infiltrating Lymphocytes Is Coincident with the Suppression of Latent Membrane Antigen-Specific CD8+ T-Cell Function in Hodgkin Lymphoma Patients. Blood 2006, 108, 2280-2289. [CrossRef]

269. Wang, Y.Q.; Zhang, Y.; Jiang, W.; Chen, Y.P.; Xu, S.Y.; Liu, N.; Zhao, Y.; Li, L.; Lei, Y.; Hong, X.H.; et al. Development and Validation of an Immune Checkpoint-Based Signature to Predict Prognosis in Nasopharyngeal Carcinoma Using Computational Pathology Analysis. J. Immunother. Cancer 2019, 7, 298. [CrossRef]

270. Zhou, Y.; He, C.; Wang, L.; Ge, B. Post-Translational Regulation of Antiviral Innate Signaling. Eur. J. Immunol. 2017, 47, 1414-1426. [CrossRef]

271. Morrison, T.E.; Mauser, A.; Wong, A.; Ting, J.P.; Kenney, S.C. Inhibition of IFN-Gamma Signaling by an Epstein-Barr Virus Immediate-Early Protein. Immunity 2001, 15, 787-799. [CrossRef] 
272. Skinner, C.M.; Ivanov, N.S.; Barr, S.A.; Chen, Y.; Skalsky, R.L. An Epstein-Barr Virus MicroRNA Blocks Interleukin-1 (IL-1) Signaling by Targeting IL-1 Receptor 1. J. Virol. 2017, 91, e00530-e00617. [CrossRef]

273. Albanese, M.; Tagawa, T.; Buschle, A.; Hammerschmidt, W. MicroRNAs of Epstein-Barr Virus Control Innate and Adaptive Antiviral Immunity. J. Virol. 2017, 91, e01667-e01716. [CrossRef]

274. Xia, T.; O'Hara, A.; Araujo, I.; Barreto, J.; Carvalho, E.; Sapucaia, J.B.; Ramos, J.C.; Luz, E.; Pedroso, C.; Manrique, M.; et al. EBV MicroRNAs in Primary Lymphomas and Targeting of CXCL-11 by Ebv-Mir-BHRF1-3. Cancer Res. 2008, 68, 1436-1442. [CrossRef]

275. Quinn, L.L.; Zuo, J.; Abbott, R.J.; Shannon-Lowe, C.; Tierney, R.J.; Hislop, A.D.; Rowe, M. Cooperation between Epstein-Barr Virus Immune Evasion Proteins Spreads Protection from CD8+ T Cell Recognition across All Three Phases of the Lytic Cycle. PLoS Pathog. 2014, 10, e1004322. [CrossRef]

276. Salek-Ardakani, S.; Arrand, J.R.; Mackett, M. Epstein-Barr Virus Encoded Interleukin-10 Inhibits HLA-Class I, ICAM-1, and B7 Expression on Human Monocytes: Implications for Immune Evasion by EBV. Virology 2002, 304, 342-351. [CrossRef]

277. Kase, K.; Kondo, S.; Wakisaka, N.; Dochi, H.; Mizokami, H.; Kobayashi, E.; Kano, M.; Komori, T.; Hirai, N.; Ueno, T.; et al. Epstein-Barr Virus LMP1 Induces Soluble PD-L1 in Nasopharyngeal Carcinoma. Microorganisms 2021, 9, 603. [CrossRef]

278. Dreyfus, D.H.; Nagasawa, M.; Pratt, J.C.; Kelleher, C.A.; Gelfand, E.W. Inactivation of NF-KappaB by EBV BZLF-1-Encoded ZEBRA Protein in Human T Cells. J. Immunol. 1999, 163, 6261-6268.

279. Chang, L.S.; Wang, J.T.; Doong, S.L.; Lee, C.P.; Chang, C.W.; Tsai, C.H.; Yeh, S.W.; Hsieh, C.Y.; Chen, M.R. Epstein-Barr Virus BGLF4 Kinase Downregulates NF-KappaB Transactivation through Phosphorylation of Coactivator UXT. J. Virol. 2012, 86, 12176-12186. [CrossRef]

280. Saito, S.; Murata, T.; Kanda, T.; Isomura, H.; Narita, Y.; Sugimoto, A.; Kawashima, D.; Tsurumi, T. Epstein-Barr Virus Deubiquitinase Downregulates TRAF6-Mediated NF-KappaB Signaling during Productive Replication. J. Virol. 2013, 87, 4060-4070. [CrossRef]

281. Van Gent, M.; Braem, S.G.; de Jong, A.; Delagic, N.; Peeters, J.G.; Boer, I.G.; Moynagh, P.N.; Kremmer, E.; Wiertz, E.J.; Ovaa, H.; et al. Epstein-Barr Virus Large Tegument Protein BPLF1 Contributes to Innate Immune Evasion through Interference with Toll-like Receptor Signaling. PLoS Pathog. 2014, 10, e1003960. [CrossRef]

282. Valentine, R.; Dawson, C.W.; Hu, C.; Shah, K.M.; Owen, T.J.; Date, K.L.; Maia, S.P.; Shao, J.; Arrand, J.R.; Young, L.S.; et al. EpsteinBarr Virus-Encoded EBNA1 Inhibits the Canonical NF-KappaB Pathway in Carcinoma Cells by Inhibiting IKK Phosphorylation. Mol. Cancer 2010, 9, 1. [CrossRef]

283. Fathallah, I.; Parroche, P.; Gruffat, H.; Zannetti, C.; Johansson, H.; Yue, J.; Manet, E.; Tommasino, M.; Sylla, B.S.; Hasan, U.A. EBV Latent Membrane Protein 1 Is a Negative Regulator of TLR9. J. Immunol. 2010, 185, 6439-6447. [CrossRef] [PubMed]

284. Stewart, S.; Dawson, C.W.; Takada, K.; Curnow, J.; Moody, C.A.; Sixbey, J.W.; Young, L.S. Epstein-Barr Virus-Encoded LMP2A Regulates Viral and Cellular Gene Expression by Modulation of the NF-KappaB Transcription Factor Pathway. Proc. Natl. Acad. Sci. USA 2004, 101, 15730-15735. [CrossRef] [PubMed]

285. Hahn, A.M.; Huye, L.E.; Ning, S.; Webster-Cyriaque, J.; Pagano, J.S. Interferon Regulatory Factor 7 Is Negatively Regulated by the Epstein-Barr Virus Immediate-Early Gene, BZLF-1. J. Virol. 2005, 79, 10040-10052. [CrossRef] [PubMed]

286. Wu, L.; Fossum, E.; Joo, C.H.; Inn, K.S.; Shin, Y.C.; Johannsen, E.; Hutt-Fletcher, L.M.; Hass, J.; Jung, J.U. Epstein-Barr Virus LF2: An Antagonist to Type I Interferon. J. Virol. 2009, 83, 1140-1146. [CrossRef]

287. Wang, J.T.; Doong, S.L.; Teng, S.C.; Lee, C.P.; Tsai, C.H.; Chen, M.R. Epstein-Barr Virus BGLF4 Kinase Suppresses the Interferon Regulatory Factor 3 Signaling Pathway. J. Virol. 2009, 83, 1856-1869. [CrossRef]

288. Bentz, G.L.; Liu, R.; Hahn, A.M.; Shackelford, J.; Pagano, J.S. Epstein-Barr Virus BRLF1 Inhibits Transcription of IRF3 and IRF7 and Suppresses Induction of Interferon-Beta. Virology 2010, 402, 121-128. [CrossRef]

289. Wood, V.H.; O’Neil, J.D.; Wei, W.; Stewart, S.E.; Dawson, C.W.; Young, L.S. Epstein-Barr Virus-Encoded EBNA1 Regulates Cellular Gene Transcription and Modulates the STAT1 and TGFbeta Signaling Pathways. Oncogene 2007, 26, 4135-4147. [CrossRef]

290. Echendu, C.W.; Ling, P.D. Regulation of Sp100A Subnuclear Localization and Transcriptional Function by EBNA-LP and Interferon. J. Interferon Cytokine Res. 2008, 28, 667-678. [CrossRef]

291. Kanda, K.; Decker, T.; Aman, P.; Wahlstrom, M.; von Gabain, A.; Kallin, B. The EBNA2-Related Resistance towards Alpha Interferon (IFN-Alpha) in Burkitt's Lymphoma Cells Effects Induction of IFN-Induced Genes but Not the Activation of Transcription Factor ISGF-3. Mol. Cell. Biol. 1992, 12, 4930-4936. [CrossRef]

292. Richardson, C.; Fielding, C.; Rowe, M.; Brennan, P. Epstein-Barr Virus Regulates STAT1 through Latent Membrane Protein 1. J. Virol. 2003, 77, 4439-4443. [CrossRef]

293. Shah, K.M.; Stewart, S.E.; Wei, W.; Woodman, C.B.; O’Neil, J.D.; Dawson, C.W.; Young, L.S. The EBV-Encoded Latent Membrane Proteins, LMP2A and LMP2B, Limit the Actions of Interferon by Targeting Interferon Receptors for Degradation. Oncogene 2009, 28, 3903-3914. [CrossRef]

294. De Pelsmaeker, S.; Romero, N.; Vitale, M.; Favoreel, H.W. Herpesvirus Evasion of Natural Killer Cells. J. Virol. 2018, 92, e02105-17. [CrossRef]

295. Nachmani, D.; Stern-Ginossar, N.; Sarid, R.; Mandelboim, O. Diverse Herpesvirus MicroRNAs Target the Stress-Induced Immune Ligand MICB to Escape Recognition by Natural Killer Cells. Cell. Host. Microbe 2009, 5, 376-385. [CrossRef]

296. Xing, Y.; Ruan, G.; Ni, H.; Qin, H.; Chen, S.; Gu, X.; Shang, J.; Zhou, Y.; Tao, X.; Zheng, L. Tumor Immune Microenvironment and Its Related MiRNAs in Tumor Progression. Front. Immunol. 2021, 12, 624725. [CrossRef] 
297. Salemme, V.; Centonze, G.; Cavallo, F.; Defilippi, P.; Conti, L. The Crosstalk Between Tumor Cells and the Immune Microenvironment in Breast Cancer: Implications for Immunotherapy. Front. Oncol. 2021, 11, 610303. [CrossRef]

298. Li, J.; Qian, C.N.; Zeng, Y.X. Regulatory T Cells and EBV Associated Malignancies. Int. Immunopharmacol. $2009,9,590-592$. [CrossRef]

299. Tao, D.; Zhang, N.; Huang, Q.; Ge, C.; Li, Q.; Li, S.; Weng, K.; Guo, Q.; Sui, J.; Wang, C.; et al. Association of Epstein-Barr Virus Infection with Peripheral Immune Parameters and Clinical Outcome in Advanced Nasopharyngeal Carcinoma. Sci. Rep. 2020, 10, 21976. [CrossRef]

300. Hu, B.; Sun, M.; Wang, Z.; Zheng, Y.; Cai, W.; Shi, H.H.; Zhuang, Y.; Lin, Q. Prognostic Value of Programmed Cell DeathLigand 1 Expression in Tumor-Infiltrating Lymphocytes and Viral Load in Peripheral Blood Mononuclear Cells for Epstein-Barr Virus-Positive Nasopharyngeal Carcinoma. Clin. Chem. 2020, 66, 1219-1227. [CrossRef]

301. Schreck, S.; Friebel, D.; Buettner, M.; Distel, L.; Grabenbauer, G.; Young, L.S.; Niedobitek, G. Prognostic Impact of TumourInfiltrating Th2 and Regulatory T Cells in Classical Hodgkin Lymphoma. Hematol. Oncol. 2009, 27, 31-39. [CrossRef]

302. Granai, M.; Lazzi, S.; Mancini, V.; Akarca, A.; Santi, R.; Vergoni, F.; Sorrentino, E.; Guazzo, R.; Mundo, L.; Cevenini, G.; et al Burkitt Lymphoma with a Granulomatous Reaction: An M1/Th1-Polarised Microenvironment Is Associated with Controlled Growth and Spontaneous Regression. Histopathology 2021. [CrossRef]

303. Ozturk, V.; Yikilmaz, A.S.; Kilicarslan, A.; Bakanay, S.M.; Akinci, S.; Dilek, I. The Triple Positivity for EBV, PD-1, and PD-L1 Identifies a Very High Risk Classical Hodgkin Lymphoma. Clin. Lymphoma Myeloma Leuk. 2020, 20, e375-e381. [CrossRef]

304. Nakayama, A.; Abe, H.; Kunita, A.; Saito, R.; Kanda, T.; Yamashita, H.; Seto, Y.; Ishikawa, S.; Fukayama, M. Viral Loads Correlate with Upregulation of PD-L1 and Worse Patient Prognosis in Epstein-Barr Virus-Associated Gastric Carcinoma. PLoS ONE 2019, 14, e0211358. [CrossRef]

305. Chan, T.S.Y.; Hwang, Y.Y.; Khong, P.L.; Leung, A.Y.H.; Chim, C.S.; Tse, E.W.C.; Kwong, Y.L. Low-Dose Pembrolizumab and Nivolumab Were Efficacious and Safe in Relapsed and Refractory Classical Hodgkin Lymphoma: Experience in a ResourceConstrained Setting. Hematol. Oncol. 2020, 38, 726-736. [CrossRef]

306. Kim, D.H.; Bae, G.E.; Suh, K.S.; Ryuman, D.; Song, K.S.; Kim, J.S.; Lee, S.I.; Yeo, M.K. Clinical Significance of Tumor and Immune Cell PD-L1 Expression in Gastric Adenocarcinoma. In Vivo 2020, 34, 3171-3180. [CrossRef]

307. Zhao, R.; Wan, Q.; Wang, Y.; Wu, Y.; Xiao, S.; Li, Q.; Shen, X.; Zhuang, W.; Zhou, Y.; Xia, L.; et al. M1-like TAMs Are Required for the Efficacy of PD-L1/PD-1 Blockades in Gastric Cancer. Oncoimmunology 2020, 10, 1862520. [CrossRef]

308. Pereira, M.A.; Batista, D.A.M.; Ramos, M.; Cardili, L.; Ribeiro, R.R.E.; Dias, A.R.; Zilberstein, B.; Ribeiro, U.; Cecconello, I.; Alves, V.A.F.; et al. Epstein-Barr Virus Positive Gastric Cancer: A Distinct Subtype Candidate for Immunotherapy. J. Surg. Res. 2021, 261, 130-138. [CrossRef]

309. Wildeman, M.A.; Novalic, Z.; Verkuijlen, S.A.; Juwana, H.; Huitema, A.D.; Tan, I.B.; Middeldorp, J.M.; de Boer, J.P.; Greijer, A.E. Cytolytic Virus Activation Therapy for Epstein-Barr Virus-Driven Tumors. Clin. Cancer Res. 2012, 18, 5061-5070. [CrossRef]

310. Soldan, S.S.; Anderson, E.M.; Frase, D.M.; Zhang, Y.; Caruso, L.B.; Wang, Y.; Deakyne, J.S.; Gewurz, B.E.; Tempera, I.; Lieberman, P.M.; et al. EBNA1 Inhibitors Have Potent and Selective Antitumor Activity in Xenograft Models of Epstein-Barr Virus-Associated Gastric Cancer. Gastric Cancer 2021, 24, 1076-1088. [CrossRef]

311. Yu, H.; Zhang, H.; Chu, Z.; Ruan, Q.; Chen, X.; Kong, D.; Huang, X.; Li, H.; Tang, H.; Wu, H.; et al. Combination of Betulinic Acid and Chidamide Synergistically Inhibits Epstein-Barr Virus Replication through over-Generation of Reactive Oxygen Species. Oncotarget 2017, 8, 61646-61661. [CrossRef] [PubMed]

312. Zeng, Y.; Si, Y.F.; Lan, G.P.; Wang, Z.; Zhou, L.; Tang, M.Z.; Sj, O.B.; Lan, J.; Zhou, X.Y.; Wang, Y.L.; et al. LMP2-DC Vaccine Elicits Specific EBV-LMP2 Response to Effectively Improve Immunotherapy in Patients with Nasopharyngeal Cancer. Biomed. Environ. Sci. 2020, 33, 849-856. [CrossRef] [PubMed]

313. Tang, Y.; Luo, C.; Cheng, A.; Lu, S.; Xu, J.; Fu, T.; Gan, R. Expression of Latent Membrane Proteins in Epstein-Barr VirusTransformed Lymphocytes In Vitro. Mol. Med. Rep. 2014, 10, 1117-1121. [CrossRef] [PubMed]

314. Tang, X.; Zhou, Y.; Li, W.; Tang, Q.; Chen, R.; Zhu, J.; Feng, Z. T Cells Expressing a LMP1-Specific Chimeric Antigen Receptor Mediate Antitumor Effects against LMP1-Positive Nasopharyngeal Carcinoma Cells in Vitro and in Vivo. J. Biomed. Res. 2014, 28, 468-475. [CrossRef] [PubMed] 